\title{
Stereospecific Reaction of Molecular Halogens with Palladacyclopentadienes Containing Bidentate Nitrogen Ligands To Give 1,4-Dihalo-1,3-dienes via Palladium(IV) Intermediates
}

\author{
Ruud van Belzen and Cornelis J . Elsevier* \\ Institute of Molecular Chemistry, Coordination and Organometallic Chemistry, University of \\ Amsterdam, Nieuwe Achtergracht 166, 1018 WV Amsterdam, The Netherlands
}

\section{Alain Dedieu}

Laboratoire de Chimie Quantique,UMR 7551 CNRS/ ULP, Université Louis Pasteur, 4, Rue Blaise Pascal, 67000 Strasbourg, France

\section{Nora Veldman ${ }^{\dagger}$ and Anthony L. Spek}

Bijvoet Center for Biomol ecular Research, Vakgroep Kristal- en Struktuurchemie, Utrecht University, Padualaan 8, $3584 \mathrm{CH}$ Utrecht, The Netherlands

Received J uly 22, 2002

\begin{abstract}
A synthetic and computational study concerning the reactivity of palladacycl opentadienes containing bidentate nitrogen ligands toward di halogens is described. The complexes 2,3,4,5tetrakis(carbomethoxy)palladacycl opentadiene(NN) (1a-c; N N = 9,10-bis(phenylimino)-9,10-dihydrophenanthrene (phenyl-bip, a), bis(p-tolylimino)acenaphthene ((p-tolyl)-bian, b), 2,2'-bipyridine (bpy, c)) reacted with molecular dihalogens to give $(\mathrm{E}, \mathrm{E})$-1,4-dihalo-1,2,3,4tetrakis(carbomethoxy)-1,3-butadiene and $\mathrm{PdX}_{2}(\mathrm{NN})(\mathrm{X}=\mathrm{Cl}, \mathrm{Br}, \mathrm{I})$. The palladacycles $\mathbf{1 a}, \mathbf{b}$ react at 203-208 K with bromine to give the palladium(IV) species trans,cis,cis-(E ,E )-2,3,4,5tetrakis(carbomethoxy)palladacycl opentadiene dibromide(NN) (3av and 3bv, respectively), which were observed by low-temperature ${ }^{1} \mathrm{H}$ N MR. A bove $243 \mathrm{~K}$ reductive elimination took place and the dival ent compounds (E,E)-\{1,2,3,4-tetrakis(carbomethoxy)-4-halo-1,3-butadienyl $\}$ palladium(II) bromide(NN) (4av and $\mathbf{4 b v}$ ) were cleanly obtained. Similar ( $\sigma$-1,3-dienyl)palladium halide complexes $\mathbf{4 a u}-\mathbf{4 c w}$ were prepared by reacting the palladacycles $\mathbf{1 a}-\mathbf{c}$ with a stoichiometric amount of chlorine, bromine, or iodine. The energy profile obtained from DFT-B3LYP calculations, which have been carried out using [ $(\mathrm{HNCHCHNH}) \mathrm{Pd}\left(\mathrm{C}_{4^{-}}\right.$ $\left.\left.(\mathrm{CN})_{4}\right)\right]+\mathrm{Br}_{2}$ as a model system, show that this sequence of oxidative addition of molecular halogen to the palladacyclic compound, generating a Pd(IV) species, followed by reductive elimination with formation of a carbon-halogen bond is energetically feasible. The calculations also point to the possible involvement of a $\mathrm{Pd}\left(\mathrm{Br}_{2}\right)$ complex in the early stages of the reaction. Palladacycles 6 derived from hexafluorobutyne $\left(E=C_{3}\right)$ reacted analogously, to give (E,Z)-\{1,2,3,4-tetrakis(trifluoromethyl-4-halo-1,3-butadienyl $\}$ palladium(II) hal ide(NN) compounds $\mathbf{7 u}-\mathbf{w}$ after $\mathrm{E}, \mathrm{Z}$ isomerization of the $\Delta(3,4)$ alkene bond. When the $(\sigma$-1,3-dienyl)palladium halides $\mathbf{4 a u}-\mathbf{4 c w}$ were reacted with an additional 1 equiv of another dihalogen, $Y_{2}$, it was found that an unsymmetric diene, (E,E)-\{1-X,4-Y\}-1,2,3,4-tetrakis(carbomethoxy)1,3-butadiene, was selectively formed, indicating that the intermediate $\mathrm{Pd}(\mathrm{IV})$ complex stereospecifically el iminates the (entering) apical halogen $Y$ and the dienyl fragment. Finally, several ionic compounds $\mathbf{1 0 b z}, \mathbf{1 1} \mathbf{b z}$, and $\mathbf{1 1 \mathbf { b z }}$ ' were obtained by addition of silver triflate to solutions of $\mathbf{4 b z}$ in the presence of a noncoordinating solvent or isonitriles, respectively. The X-ray crystal structures of [1,2,3,4-tetrakis(carbomethoxy)-4-iodo-1,3-butadienylpalladium(II) iodide $\sigma^{2} \mathrm{~N}^{\prime} \mathrm{N}^{\prime}-2,2^{\prime}$-bipyridyl)] (4cw) and of [1,2,3,4-tetrakis(carbomethoxy)-1,3pentadienyl palladium(II)(tert-butyl isocyanide) $\left(\sigma^{2} \mathrm{~N}, \mathrm{~N}^{\prime}-\mathrm{p}\right.$-tolyl-bian)] trifluoromethanesulfonate (11 bz) have been determined by X-ray diffraction.
\end{abstract}

\section{Introduction}

In previous studies we have shown that low-valent palladium compounds with rigid bidentate nitrogen ligands efficiently catalyze a number of carbon-element

† Deceased. coupling reactions, such as hydrogenation of alkenes and catalytic stereoselective semi-hydrogenation of alkynes to give ( $\mathrm{Z}$ )-alkenes and cascade three-component and other $\mathrm{C}-\mathrm{C}$ coupling reactions. ${ }^{1}$ We have reported the synthesis of 2,3,4,5-tetrakis(carbomethoxy)palladacyclopentadienes which contain bis(nitrogen) 
Scheme 1

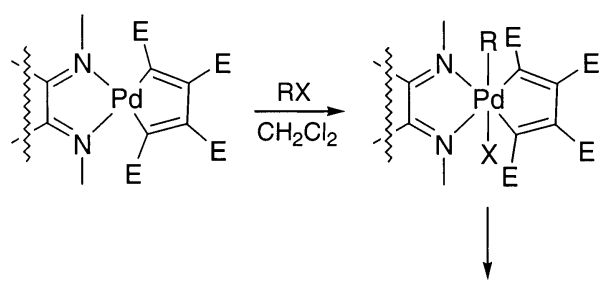

$\mathrm{E}=\mathrm{COOCH}_{3}$<smiles>[Y]C1=C(C)N(C)[Pb]([X])(/C(F)=C(F)\C(F)=C(\[R])F)N1C</smiles>

Scheme 2

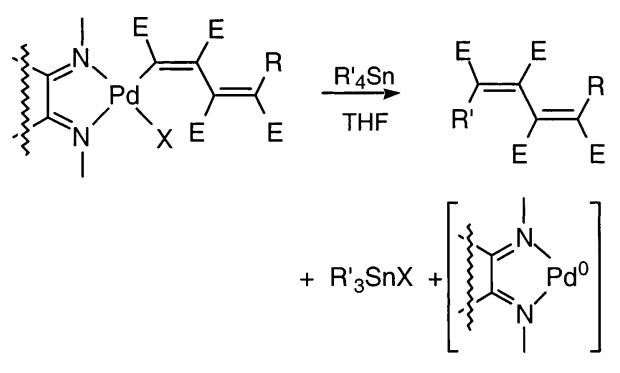

ligands of the types bis(arylimino)acenaphthene (arylBIAN) and bis(arylimino)-9,10-dihydrophenanthrene (aryl-BIP), and their reactivity toward organic halides, resulting in the formation of ( $\sigma$-1,3-dienyl)palladium complexes, has been described. These functionalized ( $\sigma$ 1,3-dienyl)palladium compounds were presumably formed by a sequence of oxidative addition of an organic halide to divalent palladium in the palladacycle, giving a transient $\mathrm{Pd}(\mathrm{IV})$ intermediate, followed by reductive elimination with the formation of a carbon-carbon bond (Scheme 1).

We also showed that subsequent transmetalation with organotin reagents led to functionalized 1,3-dienes (Scheme 2). This culminated in an efficient catalytic three-component synthesis of dienes, employing lowvalent $\mathrm{Pd}(\mathrm{NN})$ complexes as the precatalysts for a onepot protocol involving an electron-poor acetylene, an organic halide, and an organotin reagent. ${ }^{2}$

Addition-elimination sequences were also successfully attempted on the palladacyclopentadiene compounds by employing molecular halogens. Reactions of organopal ladium compounds with dihalogens have frequently been used to liberate the organic fragment from these complexes; ${ }^{3}$ for instance, oligomeric 2,3,4,5-tet-

(1) (a) van Asselt, R.; Elsevier, C. J . J . Mol. Catal. 1991, 65, L13. (b) van Asselt, R.; Elsevier, C. J . Organometallics 1992, 11, 1999. (c) van Asselt, R.; Gielens, E. E. C. G.; Rülke, R. E.; Elsevier, C. J . J . Chem. Soc., Chem. Commun. 1993, 1203. (d) van Asselt, R.; Gielens, E. E. C. G.; Rülke, R. E.; Vrieze, K.; Elsevier, C. J J . Am. Chem. Soc 1994, 116, 977. (e) van Asselt, R.; Elsevier, C. J . Tetrahedron 1994, 50, 323. (f) van Laren, M. W.; Elsevier, C. J . Angew. Chem., Int. Ed. 1999, 38, 3715

(2) (a) van Belzen, R.; H offmann, H.; Elsevier, C. J . Angew. Chem. 1997, 36, 1743. (b) van Belzen, R.; Klein, R. A.; Kooijman, H.; Veldman N.; Spek, A. L.; Elsevier, C. J. Organometallics 1998, 17, 1812.

(3) (a) Wong, P. K.; Stille, J . K. J . Organomet. Chem. 1974, 70, 121. (b) Kurosawa, H.; Urabe, A.; Miki, K.; Kasai, N. Organometallics 1986, 5, 2002. (c) I sobe, K.; Nanjo, K.; Nakamura, Y.; Kawaguchi, S. Bull. Chem. Soc. J pn. 1986, 59, 2149. (d) Albert, J .; Granell, J .; Sales, J . Polyhedron 1989, 8, 2725. (e) Kubata, M.; Boegeman, S. C.; Keill, R. N.; Webb, C. G. Organometallics 1989, 8, 1616. (f) Chattopadhyay, S. Sinha, C.; Basu, P.; Chakravorty, A. J . Organomet. Chem. 1991, 414, 421.

\section{Scheme 3}

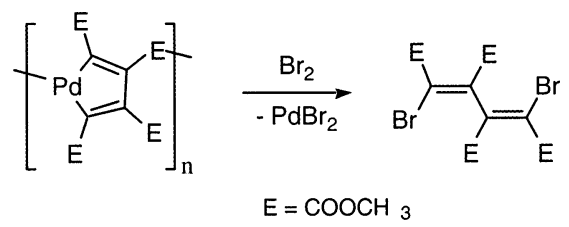

rakis(carbomethoxy)palladacycl opentadiene was reacted with bromine in order to prove the structure of the palladacycle ${ }^{4}$ (as expected, the 1,4-dibromobuta-1,3diene was produced in this reaction; see Scheme 3 ).

So far, hardly any details have been obtained about the mechanism of reactions of divalent palladium compounds with dihalogens. There are, for instance, only a few examples of diorganopalladium(IV) dihalides known: i.e., one stabilized by two perfluorophenyl groups ${ }^{5}$ and one stabilized by an aryl-BIAN ligand. ${ }^{6}$ Although the selectivity of the reductive elimination has been investigated for cationic $^{7}$ and neutral 6,8 tris(organo)palladium(IV) complexes, this is not the case for tris(halogen)palladium(IV) compounds. Some preliminary work has been published.2a

It has been shown that aryl-BIAN is able to stabilize palladium complexes in the zero-, di- and tetravalent oxidation states. ${ }^{6,9} \mathrm{H}$ ence, aryl-BIAN and aryl-BIP can most probably be employed for the identification and isolation of intermediates (e.g. neutral Pd(IV) complexes) in the formation of dienes in the reaction of palladacyclopentadienes with dihalogens.

In this paper the reactions of palladacyclopentadienes with dihalogens are described and a computational study concerning possible modes of addition of bromine is presented. The mechanism of these reactions will be discussed. Furthermore, the synthesis of cationic dienylpalladium(II) compounds and some of their reactions are described.

\section{Experimental Section}

All reactions were performed in an atmosphere of dry nitrogen using standard Schlenk techniques. All solvents were distilled prior to use. ${ }^{1} \mathrm{H}$ and ${ }^{13} \mathrm{C}\left\{{ }^{1} \mathrm{H}\right\}$ NMR spectra were recorded on a Bruker AMX 300 spectrometer (300.13 and 75.48 $\mathrm{MHz}$, respectively). Chemical shift values are in ppm relative to TMS with high-frequency shifts assigned positive. ${ }^{19} \mathrm{~F} \mathrm{NMR}$ data were collected on a Bruker AC 100 spectrometer (94.20 $\mathrm{MHz}$ ) relative to $\mathrm{CFCl}_{3}$. Mass spectra were obtained on a Varian MAT 711 double-focusing mass spectrometer and were performed by the Institute for Mass Spectroscopy, University of Amsterdam. GC-MS data were obtained using an HP 510

(4) Moseley, K.; Maitlis, P. M. J . Chem. Soc., Chem. Commun. 1971, 1604.

(5) (a) Uson, R.; Fornies, J .; Navarro, R. J . Organomet. Chem. 1975, 96, 307. (b) Uson, R.; Fornies, J .; Navarro, R. Synth. React. Inorg. Met.Org. Chem. 1977, 7, 235.

(6) van Asselt, R.; Rijnberg, E.; Elsevier, C. J . Organometallics 1994 $13,706$.

(7) de Graaf, W.; Boersma, J .; Grove, D. M.; Spek, A. L.; van Koten, G. Recl. Trav. Chim. Pays-Bas 1988, 107, 299.

(8) (a) Canty, A. L.; Watson, A. A.; Skelton, B. W.; White, A. H. J Organomet. Chem. 1989, 367, C25. (b) Byers, P. K.; Canty, A. L.; Traill, P. R.; Watson, A. A. J . Organomet. Chem. 1989, 390, 399. (c) de Graaf W.; Boersma, J .; van Koten, G. Organometallics 1990, 9, 1479. (d) Byers, P. K.; Canty, A. L.; Skelton, B. W.; Traill, P. R.; Watson, A. A White, A. H. Organometallics 1990, 9, 3080. (e) Markies, B. A.; Canty, A. L.; J anssen, M. D.; Spek, A. L.; Boersma, J .; van Koten, G. Redl. Trav. Chim. Pays-Bas 1991, 110, 477.

(9) (a) van Asselt, R.; Elsevier, C. J .; Smeets, W. J . J .; Spek, A. L. Inorg. Chem. 1994, 33, 1521. (b) van Asselt, R.; Elsevier, C. J .; Smeets, W. J. J .; Spek, A. L.; Benedix, R. Recl. Trav. Chim. Pays-Bas 1994 $113,88$. 
instrument with an 80 mesh column of $25 \mathrm{~m}$. Elemental analysis were carried out by Dornis und Kolbe, Mikroanalytisches Laboratorium, Mülheim a.d. Ruhr, Germany. The starting materials phenyl-BIP, ${ }^{10}$ (p-tolyl)-BIAN $,{ }^{9 b} \mathrm{Pd}(\mathrm{DBA})_{2},{ }^{11}$ iodobenzene dichloride, ${ }^{12}$ and the palladacyclopentadienes $\mathbf{1}$ and $\mathbf{6}^{2}$ were prepared according to literature procedures.

Synthesis of 1,4-Dihalobuta-1,3-dienes. (E,E)-1,4-Dibromo-1,2,3,4-tetrakis(carbomethoxy)buta-1,3-diene (2v). An excess of bromine $(0.5 \mathrm{~mL})$ was added to a solution of 100 $\mathrm{mg}$ of $\mathbf{1 a}(0.13 \mathrm{mmol})$ in dichloromethane $(20 \mathrm{~mL})$. After the mixture was stirred for $10 \mathrm{~min}$ at room temperature, the solvent was removed by evaporation at reduced pressure and the organic product was extracted with diethyl ether $(2 \times 20$ $\mathrm{mL}$ ). The recovered (NN) $\mathrm{PdBr}_{2}$ complex and the dibromodiene 2v were obtained in almost quantitative (>98\%) yield. Data for these compounds have been published.2a

(E,E)-1,4-Dichloro- (2u) and (E,E)-1,4-Diiodo-1,2,3,4tetrakis(carbomethoxy)buta-1,3-diene (2w). These 1,4dihalo-1,3-dienes were obtained in the same way and in almost quantitative yield by bubbling through chlorine for $1 \mathrm{~min}$ and immediate workup, or adding a 5-fold excess of iodine to the solution, followed by stirring at room temperature for $2 \mathrm{~h}$ and consecutive workup as described above. Yields were typically 95\%. Data have been published.2a

Synthesis of (E,E )-\{1,2,3,4-Tetrakis(carbomethoxy)-4 halo-1,3-butadienyl \} palladium(II) Halides with Bidentate N-Ligands (4au-4cw). To a solution of $150 \mathrm{mg}$ of 2,3,4,5-tetrakis(carbomethoxy)palladacyclopentadiene(phenylbip) (1a; $0.2 \mathrm{mmol})$ in dichloromethane $(10 \mathrm{~mL})$ was added a solution of 1 equiv of bromine $(10 \mu \mathrm{L})$ in dichloromethane (10 $\mathrm{mL}$ ) dropwise at $0{ }^{\circ} \mathrm{C}$. After addition, the solution was warmed to room temperature, after which the sol vent was removed by evaporation and the product was washed with diethyl ether $(2 \times 20 \mathrm{~mL})$ and then air-dried. The yield of $4 a v$ was $175 \mathrm{mg}$ (0.19 $\mathbf{m m o l}, 94 \%)$. The formation of compounds $\mathbf{4 b v}$ and $\mathbf{4 c v}$ was carried out similarly using $\mathbf{l b} \mathbf{b}, \mathbf{c}$, respectively. Chlorides 4au, $\mathbf{4 b u}$, and $\mathbf{4 c u}$ were synthesized by adding a stoichiometric amount of iodobenzene dichloride to a solution of $\mathbf{1 a}-\mathbf{c}$ in dichloromethane at room temperature. Similarly, 4aw, 4bw, and $\mathbf{4 c w}$ were prepared from the same palladacycl opentadiene precursors and iodine. The yields of $\mathbf{4 a u}, \mathbf{4 b u}, \mathbf{4 c u}, \mathbf{4 b v}, \mathbf{4 c v}$, 4aw, $\mathbf{4 b w}$, and $\mathbf{4 c w}$ were all higher than $\mathbf{9 2} \%$. Crystals of $\mathbf{4 c w}$ were obtained by slow evaporation of a dichloromethane solution. Exact masses ${ }^{13}$ found (calcd): 4au, $[\mathrm{M}-\mathrm{Cl}]^{0+} 783.059$ (783.072); 4bu, [M - Cl] ${ }^{++} 85.075$ (785.088); 4cu, [M + Na] ${ }^{++}$ 638.948 (638.953), 4bv, $[\mathrm{M}+\mathrm{Na}]^{++} 932.948$ (932.946); 4cw, $[\mathrm{M}+\mathrm{H}]^{++} 800.843$ (800.842). Anal. Found (calcd) for 4cv: C, 37.46 (37.39); H, 2.78 (2.85); N, 3.88 (3.96). NMR data are reported in Tables 1 and 2 .

Synthesis of $\{1,2,3,4-T e t r a k i s(t r i f l u o r o m e t h y l)-4-h a l o-$ 1,3-butadienyl \}palladium(II) Halides with Bidentate $\mathbf{N}$ Ligands $(\mathbf{7 u}-\mathbf{7 w})$. The procedure given above could also be used to prepare the trifluoromethyl analogues of compounds 4au-4cw. When an excess of dihalogen was added to a solution of $100 \mathrm{mg}$ of 2,3,4,5-tetrakis(trifluoromethyl)palladacyclopentadiene(phenyl-BIP) $(6 ; 0.13 \mathrm{mmol})$ in dichloromethane $(20 \mathrm{~mL})$, compounds $\mathbf{7 u}-\mathbf{7 w}$ were formed within $10 \mathrm{~min}$. The solvent was removed and the solid was washed with diethyl ether, forming the products in almost quantitative yield. NMR data are reported in Tables 1 and 2 .

Synthesis of $\{1,2,3,4-T$ etrakis(carbomethoxy)-1,3-pentadienyl\}palladium(II) Bromide with Bidentate $\mathbf{N}$ Ligands (4bz and $\mathbf{4} \mathbf{c z}$ ). These compounds were prepared from $\mathbf{1 b}$ or $\mathbf{1 c}$ according to an earlier report. ${ }^{2 b}$

(10) (a) MacPherson, E. J .; Smith, J . G. Tetrahedron Lett. 1971, 27 2645. (b) van Belzen, R.; Klein, R. A.; Smeets, W. J . J .; Spek, A. L.; Benedix, R.; Elsevier, C. J. Red. Trav. Chim. Pays-Bas 1996, 115, 275.

(11) Rettig, M. F.; Maitlis, M. A. Inorg. Synth. 1977, 17, 134

(12) Vogel, A. I. A Textbook of Practical Organic Chemistry, 3rd ed.; Longmans: London, 1956.

(13) With corresponding correct isotope patterns.
Synthesis of $\{1,2,3,4-T e t r a k i s(c a r b o m e t h o x y)-1,3-p e n-$ tadienyl\} palladium(II) Trifluoromethanesulfonate with Bidentate N-Ligands (10bz and $\mathbf{1 0} \mathrm{cz})$. To $100 \mathrm{mg}(0.11$ mmol) of (1,2,3,4-tetrakis(carbomethoxy)-1,3-pentadienyl)palladium(II)((p-tolyl)-BIAN) bromide (4bz) in dichloromethane was added $32 \mathrm{mg}(0.12 \mathrm{mmol})$ of silver triflate. The solution was stirred for $30 \mathrm{~min}$, after which the silver bromide was filtered off and the solution was evaporated to dryness, leaving an orange-brown solid, which was washed with two small portions of cold diethyl ether. The yield of $\mathbf{1 0 b z}$ was $96 \%$. Similarly, the compound $\mathbf{1 0} \mathrm{cz}$ was obtained in $97 \%$ yield. Exact masses found (calcd): 10bz, [M - OTf] ${ }^{+} 765.127$ (765.143); 10cz, [M - OTf] ${ }^{+} 561.049$ (561.049). Anal. Found (calcd) for 10bz: H, 3.77 (3.26); C, 39.68 (40.55); N, 3.93 (3.94); S, 3.91 (4.51). NMR data are reported in Tables 1 and 2.

Synthesis of $\{1,2,3,4-T$ etrakis(carbomethoxy)-1,3-pentadienyl $\}$ palladium(II)(isocyanide) Trifluoromethanesulfonate with Bidentate $\mathrm{N}$-Ligands $(11 \mathrm{bz}, 11 \mathrm{cz}$, and 11.bz'). To a solution of $100 \mathrm{mg}(0.11 \mathrm{mmol})$ of $\mathbf{1 0 b z}$ in dichloromethane was added an equivalent amount, $10 \mu \mathrm{L}(0.11$ $\mathrm{mmol}$ ), of tert-butyl isocyanide. An immediate change of color took place, and the solvent was removed in vacuo after $5 \mathrm{~min}$, yielding $99 \mathrm{mg}(0.10 \mathrm{mmol}, 94 \%)$ of the product $\mathbf{1 1 b z}$. Compounds $\mathbf{1 1} \mathbf{c z}$ and $\mathbf{1 1} \mathbf{b z}$ ' were prepared in a similar way in yields higher than $90 \%$. Exact masses found (calcd): $\mathbf{1 1 b z}$, $\left[\mathrm{M} \text { - OTf] }{ }^{++} 848.193 \text { (848.216); 11bz, [M - OTf] }\right]^{+} 644.132$ (644.122); 11bz' [M - OTf] ${ }^{++} 896.1908$ (896.2163). NMR data are reported in Tables 1 and 2 .

Computational Studies. Most of the calculations were carried out at the DFT-B3LYP level ${ }^{14}$ with the Gaussian 98 program, ${ }^{15}$ using as a model the $(\mathrm{HN}=\mathrm{CH}-\mathrm{CH}=\mathrm{NH}) \mathrm{Pd}\left[\mathrm{C}_{4}{ }^{-}\right.$ $(\mathrm{CN})_{4}$ ] system. The geometries were fully optimized by the gradient technique, with the following basis set: for Pd the LANL2DZ basis set is modified following the prescription of Couty and Hall. ${ }^{16}$ In this modified basis the innermost core electrons (up to 3d) are described by the relativistic orbitaladjusted effective core potential of $\mathrm{Hay}$ and Wadt ${ }^{17}$ and the remaining outer core and valence electrons by a [341/541/31] basis set where the two outermost $5 p$ functions of the standard LANL2DZ basis set have been replaced by a [41] split of the $5 p$ function optimized by Couty and Hall. ${ }^{16} \mathrm{~F}$ or the $\mathrm{Br}$ atoms the quasi-relativistic energy-adjusted spin-averaged effective core potential was taken from the work of the Stuttgart group, together with their [31/31] basis set, ${ }^{18}$ to which $s$ and $p$ diffuse functions (with exponents of 0.0493 and 0.0363 , respectively), and a d polarization function (of exponent 0.381) were added, following Radom et al. ${ }^{19}$ With this basis set the $\mathrm{Br}-\mathrm{Br}$ bond distance in $\mathrm{Br}_{2}$ is computed to be $2.323 \AA$ at the DFT-B3LYP level and $2.306 \AA$ at the MP2 level. The slight overestimation with respect to the experimental value $(2.278 \AA)$ is a welldocumented feature for the singly polarized split-val ence type

(14) (a) Becke, A. D. Phys. Rev. A 1988, 38, 3098. (b) Lee, C.; Yang W.; Parr, R. G. Phys. Rev. B 1988, 37, 785. (c) Becke, A. D. J . Chem Phys. 1993, 98, 5648.

(15) Frisch, M. J .; Trucks, G. W.; Schlegel, H. B.; Scuseria, G. E. Robb, M. A.; Cheeseman, J . R.; Zakrzewski, V. G.; Montgomery, J. A J r.; Stratmann, R. E.; Burant, J . C.; Dapprich, S.; Millam, J. M.; Daniels, A. D.; Kudin, K. N.; Strain, M. C.; Farkas, O.; Tomasi, J.; Barone, V.; Cossi, M.; Cammi, R.; Mennucci, B.; Pomelli, C.; Adamo, C.; Clifford, S.; Ochterski, J .; Petersson, G. A.; Ayala, P. Y.; Cui, Q. Morokuma, K.; Malick, D. K.; Rabuck, A. D.; Raghavachari, K.; Foresman, J . B.; Cioslowski, J .; Ortiz, J . V.; Stefanov, B. B.; Liu, G. Liashenko, A.; Piskorz, P.; Komaromi, I.; Gomperts, R.; Martin, R. L.; Fox, D. J .; Keith, T.; Al-Laham, M. A.; Peng, C. Y.; Nanayakkara, A.; Gonzalez, C.; Challacombe, M.; Gill, P. M. W.; J ohnson, B. G.; Chen W.; Wong, M. W.; Andres, J. L.; Head-Gordon, M.; Replogle, E. S. Pople, J . A. Gaussian 98, revision A.5; Gaussian, Inc.: Pittsburgh, PA 1998.

(16) Couty, M.; Hall, M. B. J . Comput. Chem. 1996, 17, 1359.

(17) Hay, P. I : Wadt, W. R. J . Chem. Phys. 1985, 82, 299.

(18) Bergner, A.; Dolg, M.; Küchle, W.; Stoll, H.; Preuss, H. Mol. Phys. 1993, 80, 1431.

(19) Glukhovtsev, M.; Pross, A.; McGrath, M. P.; Radom, L. J . Chem Phys. 1995, 103, 1878. 
Table 1. ${ }^{1} \mathrm{H}$ NMR Data of Compounds $4 a u-4 c w, 7 u-7 w$, and $10 b z-11 c z^{a}$

\begin{tabular}{|c|c|c|c|c|c|c|c|c|c|c|c|c|c|}
\hline \multicolumn{3}{|c|}{ compd } & \multirow[b]{2}{*}{$\mathrm{E}$} & \multicolumn{10}{|c|}{ proton(s) } \\
\hline no. & NN & $x$ & & 1 & 2 & 3 & 4 & 5 & 6 & 7 & 8 & 9 & $\mathrm{R}$ \\
\hline 4 4au & bip & $\mathrm{Cl}$ & $\begin{array}{c}4.03,3.74 \\
3.73,3.58\end{array}$ & $\begin{array}{c}6.82(d, \\
7.5)\end{array}$ & $b$ & $b$ & $7.85,7.80$ & & & $b$ & $b$ & $b$ & \\
\hline $4 a v$ & bip & $\mathrm{Br}$ & $\begin{array}{l}4.02,3.75 \\
3.74,3.60\end{array}$ & $\begin{array}{c}6.81(\mathrm{~d} \\
8.0)\end{array}$ & b & $\mathrm{b}$ & $7.85,7.79$ & & & b & $\mathrm{b}$ & b & \\
\hline $4 \mathrm{bu}$ & bian & $\mathrm{Cl}$ & $\begin{array}{l}3.94,3.80 \\
3.75,3.56\end{array}$ & $\begin{array}{c}6.64 \\
6.95\end{array}$ & 7.45 m & $\begin{array}{c}8.03(d, \\
8.3)\end{array}$ & & & & $\begin{array}{c}7.21(\mathrm{~d}, \\
8.0)\end{array}$ & $\begin{array}{c}7.33^{c}(d, \\
8.2)\end{array}$ & & $\begin{array}{c}2.45,2.44 \\
\left(\mathrm{CH}_{3}\right)\end{array}$ \\
\hline $4 b v$ & bian & $\mathrm{Br}$ & $\begin{array}{l}3.86,3.71 \\
3.69,3.56\end{array}$ & $6.7 \mathrm{~m}$ & $\begin{array}{c}7.43 \mathrm{t} \\
7.7\end{array}$ & $\begin{array}{c}8.01(\mathrm{~d}, \\
8.1)\end{array}$ & & & & $7.13 \mathrm{br}$ & $\begin{array}{c}7.33(\mathrm{~d} \\
7.3)\end{array}$ & & $2.46\left(\mathrm{CH}_{3}-\right)$ \\
\hline 4bw & bian & I & $\begin{array}{c}3.78,3.73 \\
3.65,3.54\end{array}$ & $\begin{array}{c}6.84(\mathrm{~d} \\
7.2)\end{array}$ & $7.4 \mathrm{~m}$ & $8.11 \mathrm{~m}$ & & & & $7.1 \mathrm{~m}$ & $7.3 \mathrm{~m}$ & & $\begin{array}{c}2.50,2.44 \\
\left(\mathrm{CH}_{3}\right)\end{array}$ \\
\hline $4 \mathrm{cu}$ & bpy & $\mathrm{Cl}$ & $\begin{array}{c}3.89,3.76 \\
3.74,3.68\end{array}$ & & & $8.0 \mathrm{~m}$ & $8.0 \mathrm{~m}$ & $7.5 \mathrm{~m}$ & $9.21,9.00$ & & & & \\
\hline $4 c v$ & bpy & $\mathrm{Br}$ & $\begin{array}{c}3.90,3.76 \\
3.74,3.62\end{array}$ & & & $8.0 \mathrm{~m}$ & $8.0 \mathrm{~m}$ & $7.5 \mathrm{~m}$ & 9.429 .07 & & & & \\
\hline $4 \mathrm{cw}$ & bpy & I & $\begin{array}{c}3.87,3.78 \\
3.73,3.44\end{array}$ & & & $8.0 \mathrm{~m}$ & $8.0 \mathrm{~m}$ & $7.60,7.45$ & $9.66,9.07$ & & & & \\
\hline $7 u$ & bip & $\mathrm{Cl}$ & & $d$ & $d$ & $7.55 \mathrm{~m}$ & $7.87,7.85$ & & & $d$ & $d$ & $d$ & \\
\hline $7 v$ & bip & $\mathrm{Br}$ & & $d$ & $d$ & $7.56 \mathrm{~m}$ & $7.87,7.84$ & & & d & d & d & \\
\hline $7 w$ & bip & 1 & & d & d & $7.55 \mathrm{~m}$ & $7.87,7.84$ & & & d & d & d & \\
\hline $10 \mathrm{bz}$ & bian & $\mathrm{CH}_{3}$ & $\begin{array}{c}3.86,3.64 \\
3.54,3.28\end{array}$ & 8.12 & 7.51 & $\mathrm{vbr}$ & & & & & & & $\begin{array}{c}2.51,2.13 \\
\left(\mathrm{CH}_{3}\right)\end{array}$ \\
\hline $10 c z$ & bpy & $\mathrm{CH}_{3}$ & $\begin{array}{c}4.01,3.84 \\
3.77,3.76\end{array}$ & & & $8.91^{\mathrm{e}}(\mathrm{d}, 5.1)$ & $8.22 \mathrm{~m}$ & $7.76,7.52$ & $8.46 \mathrm{~m}$ & & & & $1.98\left(\mathrm{CH}_{3}\right)$ \\
\hline $11 b z^{f}$ & bian & $\mathrm{CH}_{3}$ & $\begin{array}{c}3.84,3.80 \\
3.79,3.63\end{array}$ & $\begin{array}{c}8.16(d \\
8.3)\end{array}$ & $7.54 \mathrm{br}$ & $\mathrm{vbr}$ & & & & n.o. & n.o. & n.o. & $\begin{array}{c}2.49,1.29 \\
\left(\mathrm{CH}_{3}\right)\end{array}$ \\
\hline $11 c z$ & bpy & $\mathrm{CH}_{3}$ & $\begin{array}{l}3.83,3.75 \\
3.66,3.25\end{array}$ & & & $8.55 \mathrm{~m}$ & $8.27,8.22$ & $7.87,7.60$ & $8.67(d, 5.4)$ & & & & $1.93\left(\mathrm{CH}_{3}\right)$ \\
\hline $11 b^{\prime} \mathrm{g}$ & bian & $\mathrm{CH}_{3}$ & $\begin{array}{l}3.86,3.73 \\
3.70,3.36\end{array}$ & $\begin{array}{c}8.17(d \\
8.3)\end{array}$ & $\begin{array}{c}7.55 \mathrm{t} \\
7.7\end{array}$ & $\mathrm{vbr}$ & & & & n.o. & n.o. & n.o. & $2.51\left(\mathrm{CH}_{3}\right)$ \\
\hline
\end{tabular}

a Recorded at $300.13 \mathrm{MHz}$ in $\mathrm{CDCl}_{3}$ at $20^{\circ} \mathrm{C}$, unless otherwise stated. For the numbering scheme, see the structural formulas. Signals are given in ppm, and coupling constants $(\mathrm{Hz})$ are given after the chemical shifts in parentheses. Abbreviations used: $\mathrm{s}=\mathrm{singlet}$, $\mathrm{d}=$ doublet, $\mathrm{m}=$ multiplet, $\mathrm{br}=$ broad, $\mathrm{vbr}=$ very broad. ${ }^{\mathrm{b}}$ Signals (multiplets at $6.9-7.5 \mathrm{ppm}$ ) could not be assigned. ${ }^{\mathrm{c}}$ This signal stems from two protons; the other doublet coincides with $\mathrm{H}(7) .{ }^{\mathrm{d}} 7.44-7.39,7.1-6.9(2 \times \mathrm{m}, 14 \mathrm{H}, \mathrm{H}(7,8,9)$ and $\mathrm{H}(1,2)) \mathrm{ppm}$; $7 \mathbf{v}$ and $\mathbf{7 w}$ exhibit the same chemical shift ranges for these protons, although the multiplet structure is not exactly the same. e Overlap with multiplet at 8.46 ppm. ${ }^{f} \mathrm{H}(7)-\mathrm{H}(11)$ too broad to observe, $\mathrm{NC}-\mathrm{C}\left(\mathrm{CH}_{3}\right)_{3} 1.29 \mathrm{ppm}$. ${ }^{\mathrm{g}} \mathrm{H}(7)-\mathrm{H}(11)$ too broad to observe, $\mathrm{NC}-\mathrm{C}_{6} \mathrm{H}_{3}\left(\mathrm{CH}_{3}\right)_{2} 2.09 \mathrm{ppm}$.

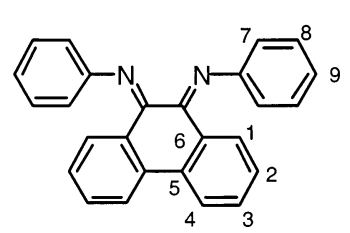

basis set. All other atoms were described by the standard LANL2DZ basis set (i.e. the Dunning-Hay [741/41] basis set for $\mathrm{C}, \mathrm{N}$, and $\mathrm{O}^{20}$ and the Huzinaga [31] basis set ${ }^{21}$ for $\mathrm{H}$ ). We refer to this basis set as BS I. The nature of the optimized structures, either transition states or intermediates, was assessed through a frequency calculation, and the changes of Gibbs free reaction energies ( $\Delta \mathrm{G}$ values) were obtained by taking into account zero-point energies, thermal motion, and entropy contribution at standard conditions (temperature of 298.15 K, pressure of $1 \mathrm{~atm}$ ). The effect of a larger basis set (hereafter referred to as BS II) was tested by single-point energy calculations at the BS I optimized geometries. In BS $\mathrm{II}$, the innermost core electrons of the palladium atom are described by the quasi-relativistic energy-adjusted spin-orbit averaged effective core potential from the Stuttgart group and the remaining outer core and val ence el ectrons by the associated triple $\xi$ basis set, ${ }^{22}$ to which an $\mathrm{f}$ polarization function of exponent $1.4722^{23}$ is added. The standard 6-311G(d,p) basis set is used for $\mathrm{C}, \mathrm{N}, \mathrm{O}$, and $\mathrm{H}^{24}$ while keeping the abovedescribed basis set and pseudopotential for $\mathrm{Br}$. Since the $\Delta \mathrm{E}$

(20) Dunning, T. H.; Hay, P. J I In Modern Theoretical Chemistry; Plenum: New York, 1976; pp 1-28.

(21) Huzinaga, S. J . Chem. Phys. 1965, 42, 1293.

(22) Andrae, D.; Haüssermann, U.; Dolg, M., Stoll, H.; Preuss, H. Theor. Chim. Acta 1990, 77, 123.

(23) Ehlers, A. W.; Böhme, M.; Dapprich, S.; Gobbi, A.. Höllwarth, J . V.; Köhler, K. F.; Stegmann, R.; Veldkamp, A.; Frenking, G. Chem. Phys. Lett. 1993, 208, 237.<smiles>Cc1ccc(N=C2C(=N)c3cccc4cccc2c34)cc1</smiles><smiles>c1ccc(-c2cccnc2)nc1</smiles>

value results obtained with $\mathrm{BSI}$ and $\mathrm{BSII}$ for the oxidative addition of $\mathrm{Br}_{2}$ and for the reductive elimination of the $\sigma$-dienyl complex turned out to be very similar (vide infra), we will concentrate our discussion on the BSI results and the corresponding free energy values.

As the DFT method is known to be somewhat deficient to describe van der Waals complexes, ${ }^{25,26}$ additional MP2 calculations were carried out using BSI for the $\mathrm{Br}_{2}$ adduct of the reacting $\mathrm{Pd}$ complex. The corresponding stabilization energy was corrected from the basis set superposition error ${ }^{27}$ through the counterpoise method ${ }^{28}$ in both cases. Although this counterpoise correction is quite large at the MP2 level $(8.2 \mathrm{kcal} /$ $\mathrm{mol})$, it is low at the DFT-B3LYP level $(1.1 \mathrm{kcal} / \mathrm{mol})$. This justifies our use, throughout this paper, of noncorrected values at that level.

Since none of the experimental systems $\mathbf{l a - c}$ were computationally tractable, in particular with respect to their reactivity with $\mathrm{Br}_{2}$, we looked for a more suitable model of the tetrakis(carbomethoxy)metallacyclopentadiene moiety and of the various bidentate $\mathrm{N}$-ligands. This was done by carrying

(24) Krishnan, R.; Binkley, J . S.; Seeger, R.; Pople, J . A. J . Chem. Phys. 1980, 72, 650 .

(25) Chalasinski, G.; Szczesniak, M. Chem. Rev. 2000, 100, 4227. (26)

(27) van Duijneveldt, F. B.; van Duijneveldt-van de Rijdt, J . G. C.

M.; van Lenthe, J. H. Chem. Rev. 1994, 94, 1873.

(28) Boys, S. F.; Bernardi, F.; Mol. Phys. 1970, 19, 553. 


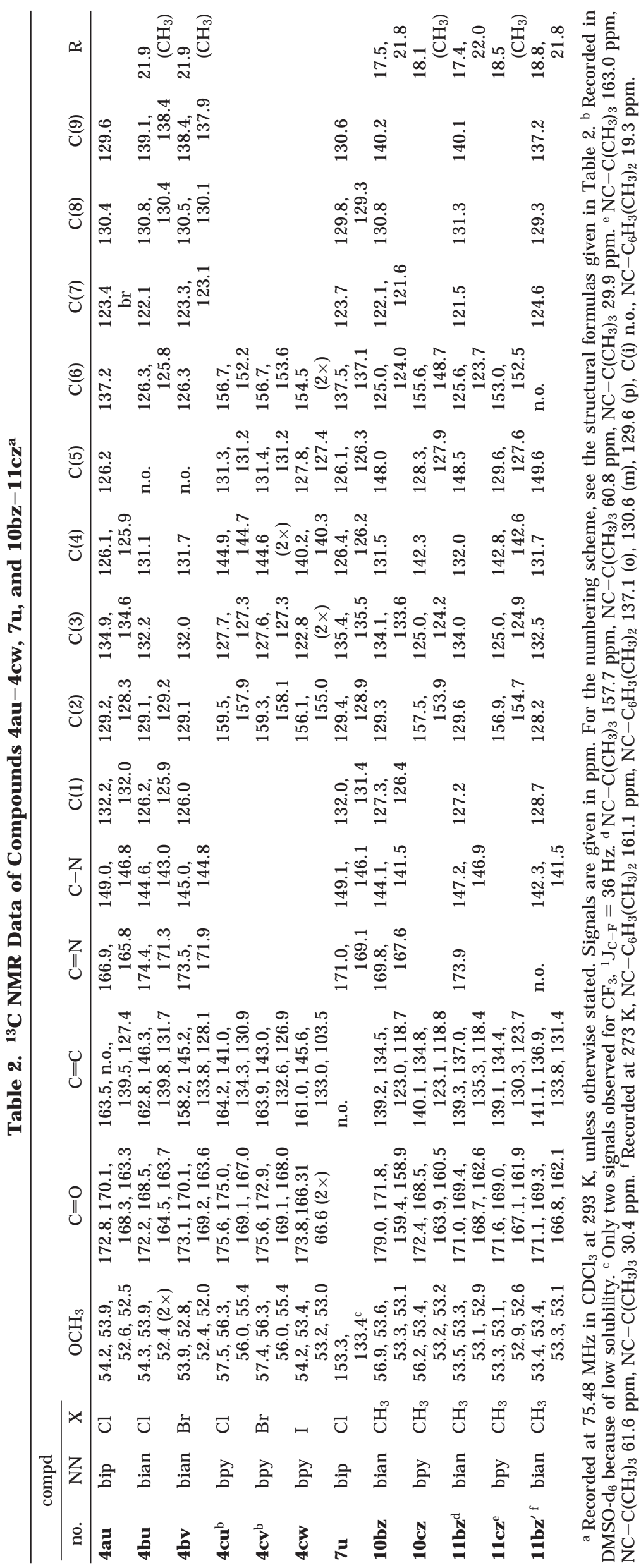


Table 3. Some Optimized Bond Distances (in Å) and DFT-B3LYP/LANL 2DZ Computed Atom Charges for Various

(Bis-imino)palladacyclopentadienes

\begin{tabular}{|c|c|c|c|c|c|c|}
\hline & $\begin{array}{c}\mathrm{Pd}-\mathrm{N} \\
(\AA)\end{array}$ & $\begin{array}{c}\mathrm{Pd}-\mathrm{C}_{\alpha} \\
(\AA)\end{array}$ & $\mathrm{Q}(\mathrm{Pd})$ & $\mathrm{Q}(\mathrm{N})$ & $\mathrm{Q}\left(\mathrm{C}_{\alpha}\right)$ & $\mathrm{Q}(\mathrm{C}$ \\
\hline & 2.140 & 2.039 & +0.235 & -0.368 & -0.330 & +0.0 \\
\hline & & & & -0.3 & +0.011 & +0.2 \\
\hline $1-c$ & & & +0.3 & -0.356 & -0.038 & +0.2 \\
\hline $\mathrm{OMe}^{\mathrm{b}}$ & & & & & -0.0 & \\
\hline & & & $+0.2]$ & -0.224 & -0.275 & -0. \\
\hline $1 c^{-}$ & 2.191 & 2.074 & +0.285 & -0.231 & -0.006 & +0.2 \\
\hline & & & & & & \\
\hline
\end{tabular}

${ }^{a} C_{2 v}$ symmetry has been assumed. ${ }^{b} C_{2}$ symmetry has been assumed. ' Experimental values. ${ }^{2 b}$

out pil ot calculations, first on the (bis-imino)palladacycl opentadiene $(\mathrm{HN}=\mathrm{CH}-\mathrm{CH}=\mathrm{NH}) \mathrm{Pd}\left(\mathrm{C}_{4} \mathrm{E}_{4}\right)$ system with various $\mathrm{E}$ substituents, $\mathrm{E}=\mathrm{H}, \mathrm{F}, \mathrm{CN}, \mathrm{OH}, \mathrm{COOH}, \mathrm{COOMe}$, yielding 1_H, 1_F, 1_CN, 1_OH, 1_COOH, and 1_COOMe, respectively. We then replaced, in the case of $\mathrm{E}=\overline{\mathrm{H}}$ and $\mathrm{COOH}$, the diimine $(\mathrm{HN}=\mathrm{CH}-\mathrm{CH}=\mathrm{NH})$ ligand by the bipyridine ligand (which is one of the experimentally used ligands). We refer to these systems as $\mathbf{1 c} \mathbf{H}$ and $\mathbf{1 c} \mathbf{C} \mathbf{C O O H}$, respectively. Table 3 reports some geometric and electronic characteristics of $\mathbf{1} \mathbf{H}$, $1 \mathrm{CN}, 1 \mathrm{COOH}, 1 \mathrm{COOMe}, \mathbf{1 c} \mathbf{H}$, and $\mathbf{1 c} \mathbf{C O O H}$. For these systems the geometry optimization was performed at the B3LYP/LAN L2DZ level, retaining the $C_{2 v}$ symmetry for $\mathbf{1}_{-} \mathbf{H}$, 1C_H, and 1_CN, and the $\mathrm{C}_{2}$ symmetry for 1_COOMe and 1c_COOH. For the sake of comparison we also give in Table 3 the $\mathrm{Pd}-\mathrm{N}$ and $\mathrm{Pd}-\mathrm{C}_{\alpha}$ bond lengths obtained from the X-ray crystal structure of the 1c_COOMe system. ${ }^{2 b}$ As seen from this table, the computed values for the $\mathrm{Pd}-\mathrm{N}$ and $\mathrm{Pd}-\mathrm{C}_{\alpha}$ bond lengths in 1_CN, 1_COOH, and 1_COOMe are in good agreement with the experimental ones. That the values optimized for $\mathbf{1 c} \mathbf{C O O H}$ are relatively long can be traced to two factors: (i) the use of the $\mathrm{COOH}$ substituent instead of COOMe, see for instance the lengthening when one goes from 1_COOMe to 1_COOH, and (ii) the symmetry constraints. Indeed, a geometry optimization of $\mathbf{1} \mathbf{C O O H}$ carried out without symmetry constraints led to somewhat shorter bond lengths ( 2.100 and $2.035 \AA$ instead of 2.124 and $2.043 \AA$, respectively). It is also clear from Table 3 that the charges of the $\mathrm{Pd}, \mathrm{N}, \mathrm{C}_{\alpha}$, and $\mathrm{C}_{\beta}$ atoms of $\mathbf{1} \mathbf{C} \mathbf{C N}$ are similar to those of 1_COOMe, which in turn can be considered as the closest model of the experimental 1c_COOMe system. Thus, 1_CN appears to be a relatively good model of the experimental systems and was subsequently used throughout.

X-ray Crystal Structure Determination of [1,2,3,4 Tetrakis(carbomethoxy)-4-iodo-1,3-butadienylpalladium(II) I odide( $\sigma^{2} \mathbf{N}, \mathbf{N}^{\prime}-\mathbf{2}, \mathbf{2}^{\prime}$-bipyridyl)] (4cw). X-ray data were collected on an Enraf-Nonius CAD4-T diffractometer on a rotating anode, for a yellowish block-shaped crystal glued with inert oil to a glass fiber and transferred into the cold nitrogen stream $(150 \mathrm{~K})$. Accurate unit-cell parameters were derived from a least-squares fit of the setting angles of 25 reflections (SET4) 29 in the range $10<\theta<14^{\circ}$. Crystal data and other details of the structure determination have been collected in Table 4. An empirical correction for absorption was done with DIFABS ${ }^{30}$ (correction range 0.79:1.40) as implemented in PLATON ${ }^{31}$ The structure was solved by automated Patterson/ Fourier techniques (DIRDIF-92) 32 $^{2}$ and refined by full-matrix

(29) de Boer, J . L.; Duisenberg, A. J . M. Acta Crystallogr. 1984, A40, C410.

(30) Walker, N.; Stuart, D. Acta Crystallogr. 1983, A39, 158

(31) Spek, A. L. Acta Crystallogr. 1990, A46, C34.

(32) Beurskens, P. T.; Admiraal, G.; Beurskens, G.; Bosman, W. P.; García-Granda, S.; Gould, R. O.; Smits, J . M. M.; Smykalla, C. The DIRDIF Program System, Technical Report of the Crystallography Laboratory; University of Nijmegen, Nijmegen, The Netherlands, 1992.
Table 4. Crystal Data and Details of the Structure Determination for $\mathbf{4 c w}$ and $\mathbf{1 1 b z}$

\begin{tabular}{|c|c|c|}
\hline & $4 \mathrm{cw}$ & $11 \mathrm{bz}$ \\
\hline empirical formula & $\begin{array}{c}\text { Crystal Data } \\
\mathrm{C}_{22} \mathrm{H}_{20} \mathrm{I}_{2} \mathrm{~N}_{2} \mathrm{O}_{8} \mathrm{Pd} \text {. } \\
\mathrm{CH}_{2} \mathrm{Cl}_{2}\end{array}$ & $\begin{array}{c}\mathrm{C}_{44} \mathrm{H}_{44} \mathrm{~N}_{3} \mathrm{O}_{8} \mathrm{Pd} \cdot \\
\mathrm{CF}_{3} \mathrm{O}_{3} \mathrm{~S}\end{array}$ \\
\hline fw & 885.57 & $\begin{array}{l}\mathrm{CF}_{3} \mathrm{O}_{3} \mathrm{~S} \\
998.34\end{array}$ \\
\hline cryst syst & triclinic & monoclinic \\
\hline space group & $\mathrm{P} \overline{1}$ (No. 2) & $\mathrm{P} 2_{1} / \mathrm{C}$ (No. 14 ) \\
\hline$a(\AA)$ & $9.8078(8)$ & $13.146(3)$ \\
\hline$b(\AA)$ & $9.8873(4)$ & $19.410(4)$ \\
\hline$c(\AA)$ & $16.573(2)$ & $17.854(3)$ \\
\hline$\alpha$ (deg) & $100.129(6)$ & \\
\hline$\beta$ (deg) & $91.264(8)$ & $93.09(2)$ \\
\hline$\gamma$ (deg) & $112.304(5)$ & \\
\hline$V\left(\AA^{-3}\right)$ & $1456.7(2)$ & 4549.1(16) \\
\hline $\mathrm{Z}$ & 2 & 4 \\
\hline $\mathrm{D}(\mathrm{calcd})\left(\mathrm{g} \mathrm{cm}^{-3}\right)$ & 2.019 & 1.458 \\
\hline$F(000)(e)$ & 848 & 2048 \\
\hline$\mu(\mathrm{M} \circ \mathrm{K} \alpha)\left(\mathrm{mm}^{-1}\right)$ & 2.99 & 0.53 \\
\hline \multirow[t]{2}{*}{ cryst size (mm) } & $0.15 \times 0.15 \times 0.15$ & $0.05 \times 0.25 \times 0.50$ \\
\hline & Data Collection & \\
\hline temp (K) & 150 & 150 \\
\hline radiation $(\lambda, \AA)$ & Mo K $\alpha(0.71073)$ & MoK $\alpha(0.71073)$ \\
\hline$\theta(\min ), \theta(\max )(\mathrm{deg})$ & $1.2,27.5$ & $1.5,23.0$ \\
\hline data set & $\begin{array}{l}-11 \text { to }+12 \\
-12 \text { to }+5\end{array}$ & $\begin{array}{l}-14 \text { to }+14 \\
-21 \text { to } 0\end{array}$ \\
\hline & -21 to +21 & $0-19$ \\
\hline $\begin{array}{l}\text { no. of total, unique } \\
\text { data; } R \text { (int) }\end{array}$ & 7122,$6670 ; 0.0495$ & 6552,$6314 ; 0.0853$ \\
\hline \multirow{2}{*}{$\begin{array}{l}\text { no. of obsd data } \\
\qquad(I>2 \sigma(I))\end{array}$} & 5121 & 3543 \\
\hline & Refinement & \\
\hline $\mathrm{N}_{\text {ref, }}, \mathrm{N}_{\text {par }}$ & 6669, 347 & 6314, 590 \\
\hline$R, R_{w}, S$ & $0.0411,0.0881,1.02$ & $0.0760,0.1650,1.02$ \\
\hline max and av shift/error & $0.002,0.000$ & $0.000,0.000$ \\
\hline $\begin{array}{l}\min , \max _{\left(\mathrm{e} \AA^{-3}\right)} \text { resd dens } \\
\end{array}$ & $-0.81,1.16$ & $-0.73,0.85$ \\
\hline
\end{tabular}

least-squares on $\mathrm{F}^{2}$ with SHE LXL-93. ${ }^{33}$ Hydrogen atoms were taken into account at calculated positions, riding on their carrier atoms with $U_{\text {iso }}$ coupled to the $U_{\text {eq }}$ value of the atom they are attached to. Neutral atom scattering factors were taken from ref 34. Geometrical calculations and illustrations were done with PLATON. ${ }^{35}$

X-ray Crystal Structure Determination of [1,2,3,4Tetrakis(carbomethoxy)-1,3-pentadienylpalladium(II )(tert-butyl isocyanide) $\left(\sigma^{2} \mathrm{~N}, \mathbf{N}^{\prime}\right.$-p-tolyl-bian)] Trifluoromethanesulfonate (11 bz). X-ray data were collected for a yellowish cut-to-shape platelet crystal glued with inert oil to a glass fiber and transferred into the cold nitrogen stream (150 K) of an Enraf-N onius CAD4-T rotating-anode diffractometer. Unit-cell parameters were derived from a least-squares fit of the setting angles of 25 reflections (SET4) ${ }^{29}$ in the range $10<$ $\theta<14^{\circ}$. Crystal data and other details of the structure determination have been collected in Table 4. The structure was solved by automated Patterson/Fourier techniques (DIRDIF-92) ${ }^{32}$ and refined by full-matrix least squares on $F^{2}$ with SHELXL-93. ${ }^{33}$ A disorder model was used to describe the orientational disorder on C(41). Hydrogen atoms were taken into account at calculated positions, riding on their carrier atoms with $U_{\text {iso }}$ coupled to the $U_{\text {eq }}$ value of the atom they are attached to. Neutral atom scattering factors were taken from ref 34 . The structure contains a small void at $(0.258,0.294$, 0.397). No residual density was found in this volume. Geometrical calculations and illustrations were done with PLATON. ${ }^{35}$

(33) Sheldrick, G. M. SHEL XL -93: Program for Crystal Structure Refinement; University of Göttingen, Göttingen, Germany, 1993.

(34) International Tables for Crystallography; Wilson, A. J . C., Ed.; Kluwer Academic: Dordrecht, The Netherlands, 1992; Vol. C.

(35) Spek, A. L. Acta Crystallogr. 1990, A46, C34. 


\section{Chart 1}<smiles>c1ccc(N=C2C(=Nc3ccccc3)c3ccccc3-c3ccccc32)cc1</smiles><smiles></smiles>

a phenyl-BIP

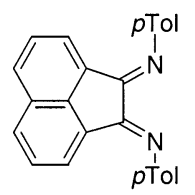

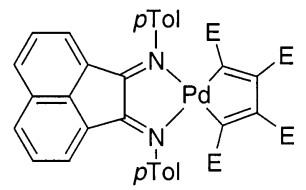

b (p-tolyl)-BIAN<smiles>c1ccc(-c2ccccn2)nc1</smiles>

c bpy

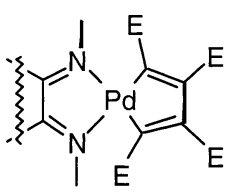

1

$\mathrm{E}=\mathrm{COOCH}_{3}$

\section{Scheme 5}

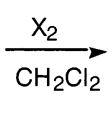<smiles>[X]C(F)=C(F)C(F)=C(F)[B-]1([Y])N(C)C(C)=C(C)N1C</smiles>

a; $N N=$ phenyl-bip

c; $\mathrm{NN}=2,2^{\prime}$-bipy b; $N N=p$-tolyl-bian
4

$\mathrm{u} ; \mathrm{X}=\mathrm{Cl}$ v; $\mathrm{X}=\mathrm{Br}$ $\mathbf{w} ; X=1$ not possible to isolate $\mathbf{4 a w}$, because when the reaction with iodine was carried out starting from $\mathbf{l a}$, a mixture of compounds was obtained. No suitable crystals of any of the ( $\sigma$-1,3-butadienyl)palladium halide compounds containing a rigid bis(nitrogen) ligand could be obtained, but we succeeded in obtaining crystals of the iodo derivative containing bipyridine $(\mathbf{4} \mathbf{c w})$.

Spectroscopic Characterization of $\sigma$-dienylpalladium(II) Halide Compounds 4. The ( $\sigma$-dienyl)palladium(II) halide compounds $\mathbf{4 a u}-\mathbf{4 c w}$ were analyzed by ${ }^{1} \mathrm{H}$ and ${ }^{13} \mathrm{C}\left\{{ }^{1} \mathrm{H}\right\}$ NMR (and mass spectroscopy $(F A B)$ or elemental analysis). Characterization of all compounds by NMR was straightforward, and all complexes exhibited the number and positions of signals according to their symmetry: i.e. four peaks for the carbomethoxy groups and doubling of the signals due to the bidentate ligand for $\mathbf{4 a u}-\mathbf{4 c w}$ (these exhibit no symmetry elements; i.e., the position of the dienyl moi ety is perpendicular to the coordination plane). The resonance signals of the $\mathrm{N}$-phenyl groups in the compl exes containing BIP appeared to be broad, as a result of the exchange between aryl protons due to intermediately rapid rotation around the $\mathrm{N}-\mathrm{C}$ (aryl) axes in the ligand. The puckering and the associated dynamic behavior of the BIP ligand on the NMR time scale has already been described in earlier work. ${ }^{2,10 b}$ The resonances in the ${ }^{1} \mathrm{H}$ NMR spectra of the $\mathrm{N}$-tolyl groups in the compounds containing ( $p$-tolyl)-BIAN are all inequivalent because the dienyl moiety is positioned perpendicularly to the plane of coordination, as was observed for $\mathbf{4 b v}$ and $\mathbf{4} \mathbf{c w}$ in solution and for the latter also in the solid stat (see below). Compounds 4av and 4bw proved to be unstable when kept in solution for extended periods of time, also at lower temperatures. Therefore, ${ }^{13} \mathrm{C}\left\{{ }^{1} \mathrm{H}\right\}$ NMR could unfortunately not be obtained for these complexes.

X-ray Structure of [1,2,3,4-Tetrakis(carbomethoxy)-4-iodo-1,3-butadienylpalladium(II) lodide ( $\sigma^{2}$ $\mathbf{N}, \mathbf{N}^{\prime}-\mathbf{2}, \mathbf{2}$-bipyridyl)] (4cw). The unit cell contains two molecules of $\mathbf{4 c w}$ and two dichloromethane molecules of crystallization. The latter show $\mathrm{C}-\mathrm{H}-\mathrm{-}-\mathrm{O}$ interactions to $\mathrm{O}(1), \mathrm{O}(3)$, and $\mathrm{O}(6)$, typical for hydrogen bonds.

The molecular structure and the adopted numbering scheme are depicted in Figure 1; selected bond distances, bond angles, and torsion angles have been compiled in Table 5.

Several crystal structure determinations of ( $\sigma$-butadienyl)palladium(II) compounds are known. Most of these compounds, however, are the product of two successive alkyne insertions into a palladium-carbon or palladium-chloride bond, and generally the two alkene moieties have a "trans + cis" type of configura- 


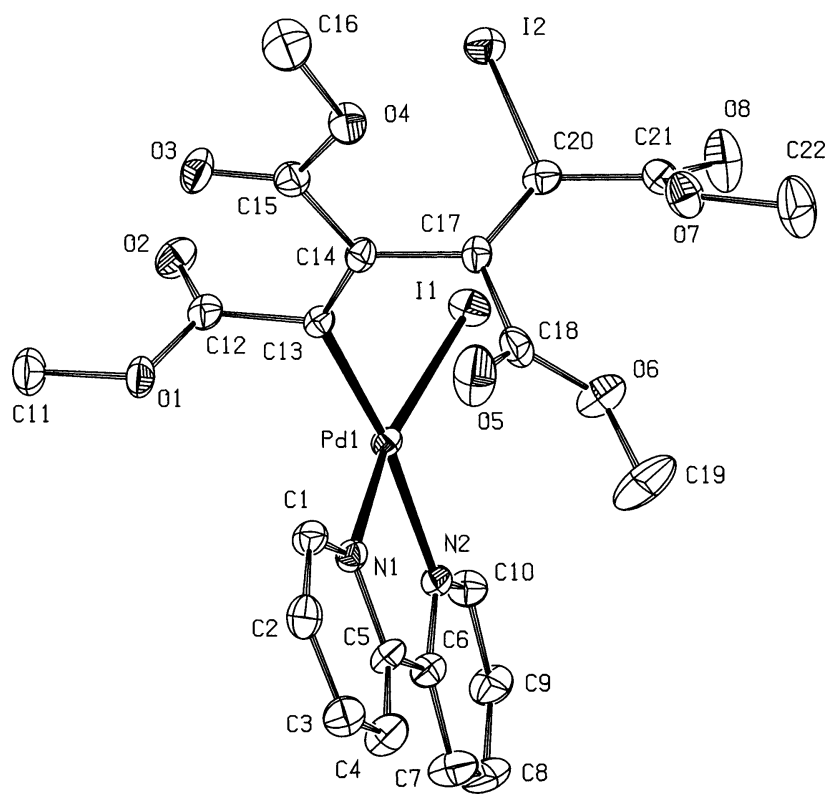

Figure 1. ORTEP presentation (50\% probability displacement ellipsoids) of $\mathbf{4 c w}$. Hydrogen atoms and $\mathrm{CH}_{2} \mathrm{Cl}_{2}$ solvent are omitted.

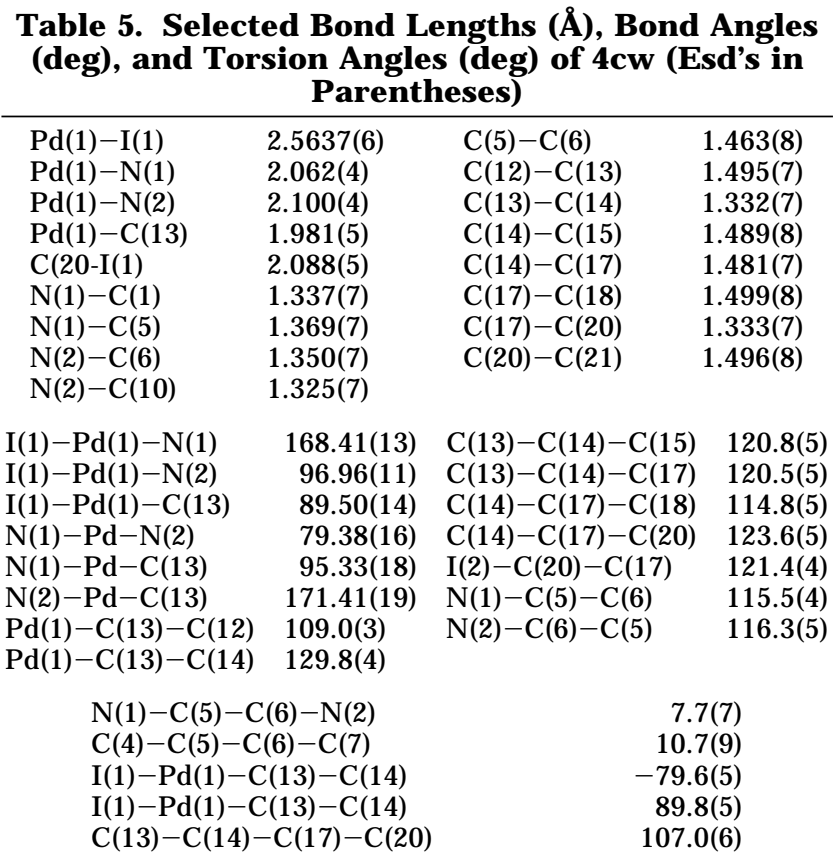

tion. ${ }^{36}$ In contrast, the configuration in complex $\mathbf{4} \mathbf{c w}$ is $\mathrm{E}, \mathrm{E}$; i.e., both sets of ester groups are cis-disposed. The butadienyl fragment is positioned perpendicularly to the coordination plane, as is also found in the comparable compound $[\mathrm{Pd}(\mathrm{C}(\mathrm{tBu})=\mathrm{CMeCMe}=\mathrm{C}(\mathrm{tBu}) \mathrm{Cl}) \mathrm{Cl}$ (bi pyridine)]. ${ }^{37}$ The features of the bipyridine and the dienyl fragment are very similar, also concerning the relative orientation of the two alkene moieties in the $\sigma$-dienyl fragment, which are in both cases al most perpendicular to each other (see Table 5). This is different from the ( $\sigma$-dienyl)palladium bis(triphenyl phosphine) complex, which has an agostic interaction involving the vinylic proton and the palladium center, and both alkenes

(36) Pfeffer, M. Recl. Trav. Chim. Pays-Bas 1990, 109, 567 and references cited therein.

(37) Kelly, E. A.; Bailey, P. M.; Maitlis, P. M. J . Chem. Soc., Chem. Commun. 1977, 289. therefore are almost coplanar. ${ }^{38}$ The $\mathrm{Pd}(1)-\mathrm{O}(5)$ distance amounts to 4.188(5) $\AA$. The bite angle of the bipyridine amounts to $79.38(16)^{\circ}$, and the torsion angle within the diimine unit of $7.7(7)^{\circ}$ is slightly larger than in the case of the palladacyclopentadiene containing bipyridine, which amounts to $1.4^{\circ} .^{2 b}$ Other features are as could be expected.

Intermediates: NMR. When the reaction of $\mathbf{l a}$ with bromine was carried out at $-70^{\circ} \mathrm{C}$ and cold pentane was added to the resultant red solution, a red precipitate was formed almost instantly. A red powder could be obtained, which was washed with cold pentane and subsequently analyzed by ${ }^{1} \mathrm{H}$ NMR at low temperature $(223 \mathrm{~K})$. The spectra revealed a large high-frequency shift for the $\alpha$-methoxy groups (from $2.93 \mathrm{ppm}$ for $\mathbf{l a}$ at $223 \mathrm{~K}$ to $3.72 \mathrm{ppm}$ for the new compound) upon addition of bromine. Two signals are observed for the four methoxy groups, one for the $\alpha$ - and one for the $\beta$-methoxy groups. The compound 3av was stable in solution at $223 \mathrm{~K}$ for several minutes. When the temperature was raised to $243 \mathrm{~K}$, conversion of 3av to the ( $\sigma$-butadienyl)palladium compound $\mathbf{4 a v}$ was observed.

Similar complexes could also be observed for reaction of $\mathbf{1 b}$ with bromine and the analogous complex containing o,o-diisopropyl-bian as outlined above. In the case of the bipyridine (1c) or triphenyl phosphine anal ogues, no $\mathrm{Pd}(\mathrm{IV})$ intermediates could be observed by means of low-temperature ${ }^{1} \mathrm{H}$ NMR, not even at $213 \mathrm{~K}$. In the case of the o,o'-diisopropyl-bian analogue of $\mathbf{1 b}$, where each of the $\mathrm{N}$-aryl groups bears two isopropyl groups at the 2- and 6-positions of the aromatic ring, the number of signals observed for the iPr methyl groups is 2 (at $\delta 1.32$ and $0.54 \mathrm{ppm}$ at $200 \mathrm{~K}$ ), due to hindered rotation of the aryl groups. Importantly, for the compound 3bv after addition of bromine, a similar spectrum was obtained; featuring two-now somewhat broadenedsignals at $\delta 1.26$ and 0.52 ppm for these methyl groups. A single set of signals due to symmetry-related halves of the bip or bian backbone was observed throughout. These data demonstrate the equival ence of both halves of the molecule within the coordination plane and above and below this plane. There is no diastereotopicity of the isopropyl methyl groups in the case of the diisopropyl-bian analogue. Altogether, the spectroscopic observations point to the formation of compounds with $\mathrm{C}_{2 \mathrm{v}}$ symmetry. The only molecular structure fitting these data is the oxidative addition product of the halogen with compounds of type $\mathbf{1}$ to give the dihalopalladium(IV) compounds of general structure 3 (Scheme 6).

In the spectra, generally some reaction products, e.g., the ( $\sigma$-dienyl)palladium complex 4 and 1,4-dibromobuta1,3-diene 2, were visible due to a slow (at $223 \mathrm{~K}$ ) reaction toward 4av. This reaction proceeds even at $223 \mathrm{~K}$ at a rate precluding the obtention of ${ }^{13} \mathrm{C} N \mathrm{NMR}$ and analysis or mass spectral data.

Intermediates: Computational Studies. The schematic energy profile $(\Delta H$ values, $\Delta G$ values in parentheses) as obtained from the calculations with the BS I basis set is shown in Scheme 7. The optimized structures of the reactants, intermediates, transition state,

(38) Roe, D. M.; Bailey, P. M.; Moseley, K.; Maitlis, P. M. J . Chem. Soc., Chem. Commun. 1972, 1273. 
Scheme 6

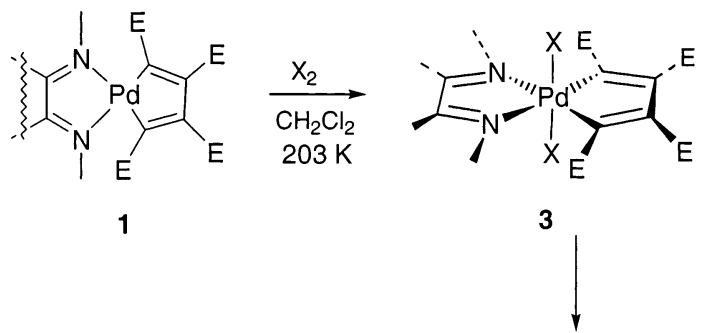

$\mathrm{E}=\mathrm{COOCH}_{3}$

a; $N N=$ phenyl-bip
b; $N N=p$-tolyl-bian

c; $N N=2,2$ '-bipy $\mathrm{u} ; \mathrm{X}=\mathrm{Cl}$
$\mathbf{v} ; \mathrm{X}=\mathrm{Br}$

$w ; X=1$

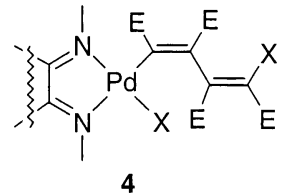

4 and products are shown in Figure 2,and the corresponding energies have been collected in Table 6.

One first finds a van der Waals type adduct between $\mathrm{Br}_{2}$ and the square-planar palladium starting compound. In the MP2-optimized structure $\mathrm{Br}_{2}$ stands at $2.73 \AA$ above the $\mathrm{Pd}$ atom, almost perpendicularly to the complex plane, the optimized $\mathrm{Pd}-\mathrm{Br}-\mathrm{Br}$ angle being $170.7^{\circ}$. Note that the corresponding DFT-B3LYP values are $2.93 \AA$ and $169.9^{\circ}$. The $\mathrm{Br}_{2}$ molecule is slightly el ongated, by $0.07 \AA$ from its free equilibrium value, as a result of some charge transfer to the empty orbitals of $\mathrm{Pd}$ : the $\mathrm{Br}_{2}$ unit is positively charged by 0.07 e (HF value). The MP2//MP2 stabilizing energy (BSSE corrected) amounts to $5.0 \mathrm{kcal} / \mathrm{mol}$, a value quite close to the uncorrected B3LYP//B3LYP value of $4.2 \mathrm{kcal} / \mathrm{mol}$ (we have already mentioned in the Computational Studies part of the Experimental Section that the counterpoise correction is quite low at the DFT level, $1.1 \mathrm{kcal} / \mathrm{mol}$ ). The trans-dibromopalladium(IV) complex is much lower in energy than the palladium(II)- $\mathrm{Br}_{2}$ adduct. The reaction energy of the oxidative addition step is computed to be $16.7 \mathrm{kcal} / \mathrm{mol}$. The corresponding free energy is of course much smaller, $-4.3 \mathrm{kcal} \mathrm{mol}^{-1}$, due to the negative entropy term. The transition state for the reductive elimination from the dibromo Pd(IV) system toward the $\sigma$-dienyl palladium complex has been optimized. Its structure is shown in Figure 2. The energy barrier ( $\Delta \mathrm{E}^{\ddagger}$ value) amounts to $25.4 \mathrm{kcal} / \mathrm{mol}$, and the corresponding free energy of activation $\left(\Delta \mathrm{G}^{\ddagger}\right.$ value) is slightly lower, amounting to $23.4 \mathrm{kcal} / \mathrm{mol}$.

The ( $\sigma$-dienyl)palladium(II) complex $\mathbf{E} 1$ reached immediately after the transition state has a structure that is quite different from the one shown in Figure 1 for the experimental iodo analogue. It is more similar to the ( $\sigma$-dienyl)palladium bis(triphenyl phosphine) compl ex mentioned above. ${ }^{38}$ The butadienyl fragment is not positioned perpendicularly to the coordination plane but makes a dihedral angle of $132.7^{\circ}$. In addition, the two alkene moieties are not perpendicular to each other (the corresponding dihedral angle amounts to $64.5^{\circ}$ ). This is most likely due to a remaining weak interaction between the palladium center and the bromine atom that has been transferred, the optimized $\mathrm{Pd} \cdot \cdots \mathrm{Br}$ distance being $3.70 \AA$. The intermediate $\mathbf{E ~ 1 , ~ w h o s e ~ e n e r g y ~}$ is $2.2 \mathrm{kcal} / \mathrm{mol}$ above the dibromo $\mathrm{Pd}(\mathrm{IV})$ system $(\Delta \mathrm{G}$

\section{Scheme 7}
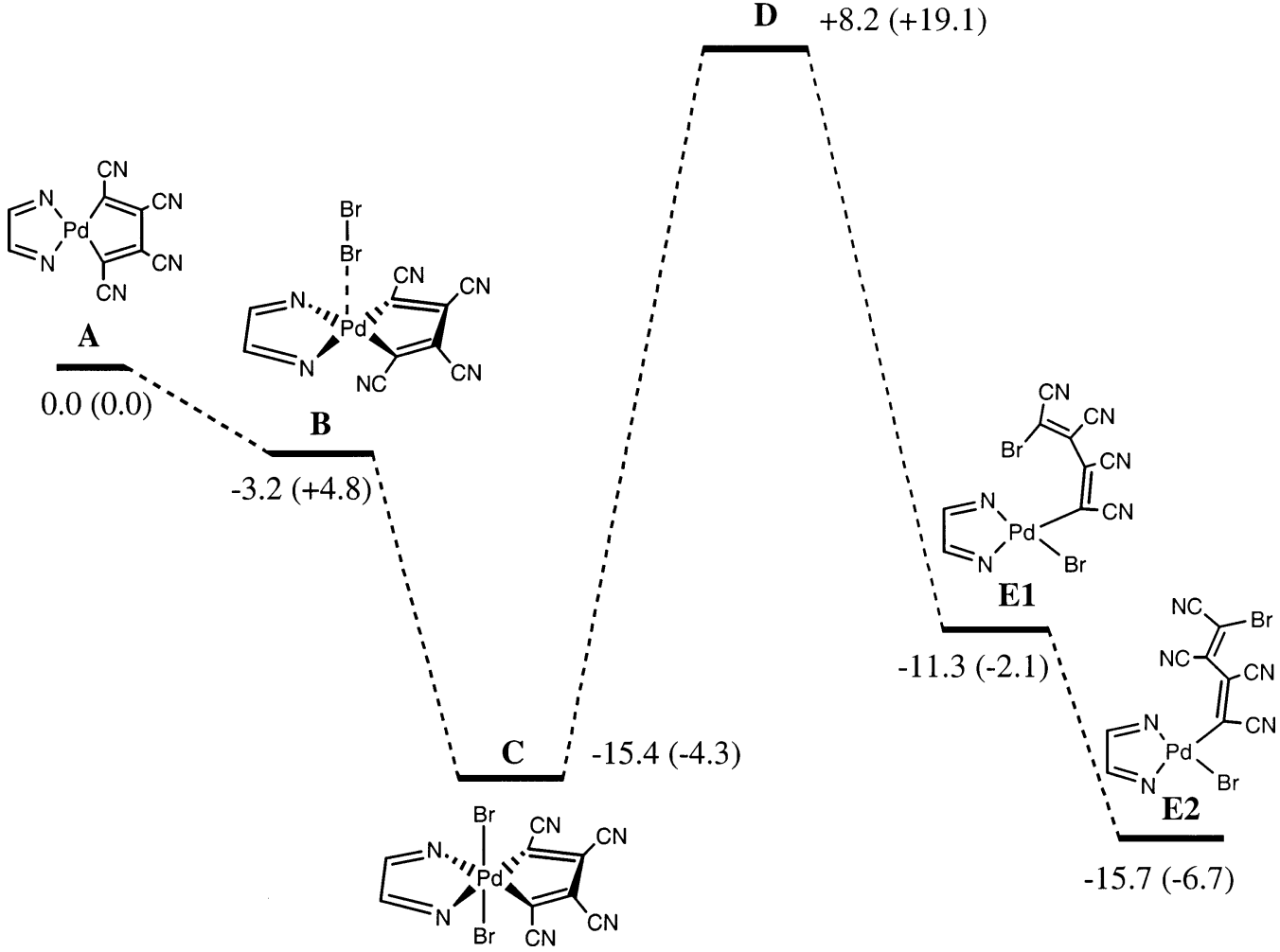<smiles>N#CC(C#N)C(C#N)C(C#N)C(Br)(C#N)[Pb]1(Br)N=CC=N1</smiles>

D $+8.2(+19.1)$ 


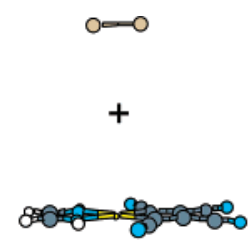

Pdll $+\mathrm{Br}_{2} \mathbf{A}$

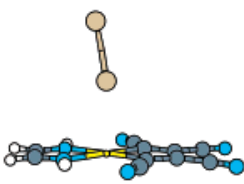

$\mathrm{Pd}(\mathrm{II}) \ldots \mathrm{Br}_{2} \mathbf{B}$

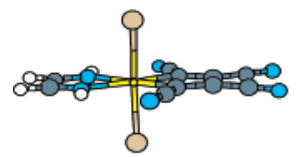

$\mathrm{Pd}(\mathrm{IV})(\mathrm{Br})_{2} \mathrm{C}$

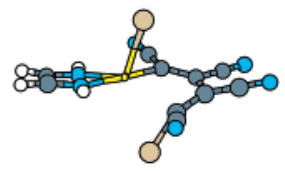

TS- $\sigma$-dienyl D

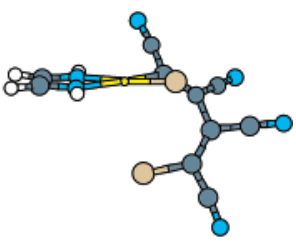

$\sigma$-dienyl complex E1

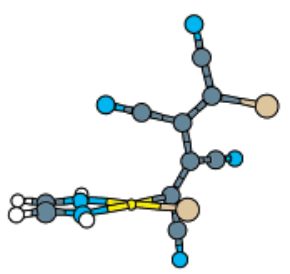

б-dienyl complex E2

Figure 2. Optimized structures (at the DFT-B3LYP/BS I (evel) of the systems $\mathbf{A}-\mathbf{E}$.

Table 6. Relative Energies ( $\Delta E)$, Enthalpies $(\Delta H)$, and $F$ ree Energies $(\Delta \mathbf{G})$ for the Reactants, Intermediates, Transition State, and Products ${ }^{a, b}$

\begin{tabular}{lccc}
\multicolumn{1}{c}{ system } & $\Delta \mathrm{E}$ & $\Delta \mathrm{H}$ & $\Delta \mathrm{G}$ \\
\hline$\left[(\mathrm{NN}) \mathrm{Pd}\left(\mathrm{C}_{4}(\mathrm{CN})_{4}\right)\right]+\mathrm{Br}_{2}(\mathbf{A})$ & 0 & 0 & 0 \\
{$\left[(\mathrm{NN}) \mathrm{Pd}\left(\mathrm{C}_{4}(\mathrm{CN})_{4}\right)\right] \cdot \mathrm{Br}_{2}(\mathbf{B})$} & -4.2 & $-3.2^{\mathrm{c}}$ & $+4.8^{\mathrm{c}}$ \\
{$\left[(\mathrm{NN}) \mathrm{Pd}\left(\mathrm{C}_{4}(\mathrm{CN})_{4}\right)(\mathrm{Br})_{2}\right](\mathbf{C})$} & -16.7 & -15.4 & -4.3 \\
& +8.4 & +8.2 & +19.1 \\
$\mathrm{TS}(\sigma-d i e n y l)(\mathbf{D})$ & $(+25.1)^{\mathrm{d}}$ & $(+23.6)^{\mathrm{d}}$ & $(+23.4)^{\mathrm{d}}$ \\
& -12.3 & -11.3 & -2.1 \\
{$\left[(\mathrm{NN}) \mathrm{Pd}(\mathrm{Br})\left(\mathrm{C}_{4}(\mathrm{CN})_{4} \mathrm{Br}\right](\mathbf{E ~ 1 )}\right.$} & $(+4.4)^{\mathrm{e}}$ & $(+4.1)^{\mathrm{e}}$ & $(+2.2)^{\mathrm{e}}$ \\
& -16.7 & -15.7 & -6.7 \\
{$\left[(\mathrm{NN}) \mathrm{Pd}(\mathrm{Br})\left(\mathrm{C}_{4}(\mathrm{CN})_{4} \mathrm{Br}\right](\mathbf{E ~ 2})\right.$} & $(0)^{\mathrm{e}}$ & $(-0.3)^{\mathrm{e}}$ & $(-2.4)^{\mathrm{e}}$
\end{tabular}

a The values are in $\mathrm{kcal}^{\mathrm{mol}}{ }^{-1}$ and refer to DFT-B3LYP calculations with the BS I basis set. (NN) stands for the $\mathrm{HN}=\mathrm{CHCH}=\mathrm{NH}$ diimine model ligand. ${ }^{b}$ The total energies of $\left[(\mathrm{NN}) \mathrm{Pd}\left(\mathrm{C}_{4}(\mathrm{CN})_{4}\right)\right]+\mathrm{Br}_{2}$ (in au) are $\mathrm{E}=-865.23600, \mathrm{H}=$ -865.08893 , and $\mathrm{G}=-865.17965$. ' Without taking into account the anharmonic correction. ${ }^{d}$ Energy barrier with respect to the dibromo Pd(IV) complex in parentheses. e Reaction energy for the reductive elimination process from the $\mathrm{Pd}(\mathrm{IV})$ dibromo complex in parentheses.

value; the corresponding $\Delta \mathrm{E}$ value is $4.4 \mathrm{kcal} / \mathrm{mol}$ ), can rearrange to another intermediate, viz. E 2, which is 4.6 $\mathrm{kcal} / \mathrm{mol}$ lower in energy ( $\Delta \mathrm{G}$ value; see Table 6$)$ and has a structure quite similar to that observed for the iodo derivative; the dihedral angle of the butadienyl fragment with the coordination plane is $99.6^{\circ}$, much closer to the experimental value of $89.8^{\circ}$ for $\mathbf{4 c w}$, and the two alkene moieties make an angle of $134.0^{\circ}$ (the experimental value for $\mathbf{4} \mathbf{c w}$ is $107.0^{\circ}$ ). We identify this

second intermediate E 2 as the final product of the reductive elimination process.

The reliability of the energies computed by the DFT method was tested by carrying out additional calculations on a similar oxidative addition/reductive elimination reaction for which experimental data are known. The reductive elimination of $\mathrm{Mel}$ from [Pt(I)Me $(\mathrm{dppe})]$ is characterized by a reaction enthalpy of $+15.8 \mathrm{kcal}$ $\mathrm{mol}^{-1}$ in acetone, from which a value of $22.5 \mathrm{kcal} \mathrm{mol}^{-1}$ in the solid state has been estimated. ${ }^{39}$ The reaction energy $\Delta \mathrm{E}$ and the reaction enthalpy $\Delta \mathrm{H}$ computed at the DFT-B3LYP level for the model reaction $\left[\mathrm{Pt}(\mathrm{I}) \mathrm{Me}_{3}-\right.$ $\left.\left(\mathrm{PH}_{3}\right)_{2}\right] \rightarrow\left[\mathrm{PtMe}_{2}\left(\mathrm{PH}_{3}\right)_{2}\right]+\mathrm{Mel}$, with a basis set similar to that used in the palladium systems, amount to +17.6 and $+15.7 \mathrm{kcal} \mathrm{mol}^{-1}$, respectively. We have also considered the $\left[\mathrm{Pt}(\mathrm{I}) \mathrm{Me}_{3}(\mathrm{dppe})\right]$ experimental system but have limited ourselves in this case to the cal culation of the reaction energy only. The corresponding $\Delta \mathrm{E}$ value is $18.9 \mathrm{kcal} / \mathrm{mol}$. All these DFT values are in good agreement with the experimental ones, as expected from related theoretical studies. ${ }^{40}$ Interestingly, the same calculation carried out at the MP2 level (on the B 3LYP optimized gemetries) led to values which are much too high: viz., $44.4 \mathrm{kcal} \mathrm{mol}^{-1}$. The fact that the MP2 level may fail to account for the thermodynamics of reductive elimination/oxidative addition reactions is a feature that we have encountered in other instances for Pt(IV)/Pt(II) or $\mathrm{Pd}(\mathrm{IV}) / \mathrm{Pd}(\mathrm{II})$ reactions. ${ }^{41} \mathrm{It}$ can also be foundsometimes less dramatically-in the literature for other systems. ${ }^{42}$

As mentioned in the Computational Studies part of the Experimental Section, we also carried out a few calculations with the larger basis set BS II. Results quite similar to the BS I ones were obtained. Thus, for the oxidative addition of $\mathrm{Br}_{2}$, the BS II computed reaction energy amounts to $-20.7 \mathrm{kcal} \mathrm{mol}^{-1}$, instead of $-16.7 \mathrm{kcal} \mathrm{mol}^{-1}$ with BS I. The energy barrier for the subsequent reductive elimination reaction of the $\sigma$-dienyl complex is $26.9 \mathrm{kcal} \mathrm{mol}^{-1}$ instead of $25.1 \mathrm{kcal}$ $\mathrm{mol}^{-1}$ with $\mathrm{BSI}$, and the corresponding reaction energy is $+0.4 \mathrm{kcal} \mathrm{mol}^{-1}$ (instead of $0.0 \mathrm{kcal} \mathrm{mol}^{-1}$ ). Finally the energy difference between the two $\sigma$-dienyl isomers $\mathbf{E} \mathbf{1}$ and $\mathbf{E} \mathbf{2}$ is computed to be $4.3 \mathrm{kcal} \mathrm{mol}^{-1}$ (instead of $4.4 \mathrm{kcal} \mathrm{mol}^{-1}$; see Table 6).

Reactions of ( $\sigma$-Dienyl)palladium(II) Halide Compounds $4 \mathrm{au}-\mathbf{4} \mathbf{c w}$ with Dihalogens. When the ( $\sigma$ dienyl)palladium compound $\mathbf{4 a v}$ was reacted with an additional 1 equiv of bromine, 1,4-dibromo-1,2,3,4tetrakis(carbomethoxy)-1,3-butadiene (2v) was formed together with (phenyl-BI P) $\mathrm{PdBr}_{2}$ (see Scheme 7). When the chloride adducts $\mathbf{4 a u}$ and $\mathbf{4 b u}$ were reacted with bromine, a selective formation of 1-bromo-4-chl orodiene was observed (Scheme 8), and when iodine was used, 1-bromo-4-iodobuta-1,3-diene was predominantly formed.

If the dihalogens were used in reversed order, i.e. the bromine adduct $\mathbf{4 a v}$ or $\mathbf{4 b v}$ was reacted with chlorine, the 1-bromo-4-chlorobuta-1,3-diene was al so obtained.

(39) Goldberg, K. I.; Yan, J .-Y.; Breitung, E. M. J . Am. Chem. Soc. 1995, 117, 6889

(40) (a)'Bartlett, K. L.; Goldberg, K. I.; Borden, W. T. J . Am. Chem. Soc. 2000, 122, 1456. (b) Bartlett, K. L.; Goldberg, K. I.; Borden, W. T Organometallics 2001, 20, 2669 and references therein.

(41) (a) Milet, A. Ph.D. Dissertation, Strasbourg, Germany, 1997. (b) Milet, A.; Dedieu. A. Unpublished results.

(42) See Table 21 in: Niu, S.; Hall, M. B. Chem. Rev. 2000, 100, 415. 


\section{Scheme 8}

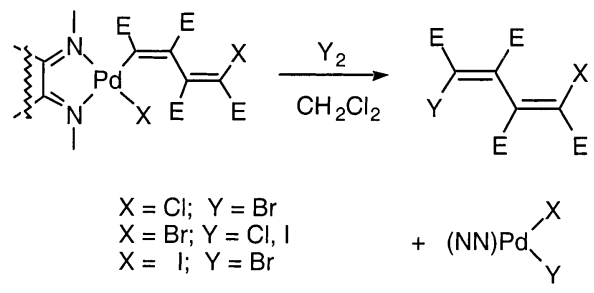

Scheme 9
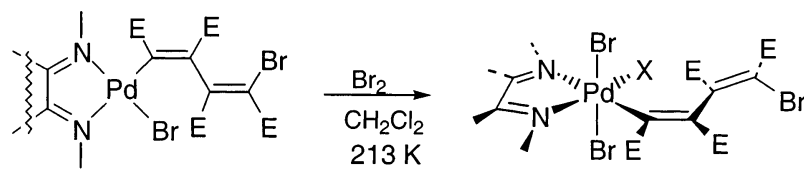

4av, 4bv

a, $N N=$ phenyl-bip

b; $\mathrm{NN}=p$-tolyl-bian

$\mathrm{E}=\mathrm{COOCH}_{3}$ 5av, $5 \mathrm{bv}$

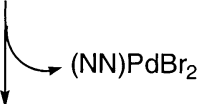<smiles>CC(=C(F)Br)C(F)=C(F)Br</smiles>

When these palladium complexes were reacted with chloro-iodide, a mixture of 1-bromo-4-chloro-1,3-butadiene (90\%) and 1-chloro-4-iodo-1,3-butadiene (10\%) was obtained, but, importantly, no 1,4-dibromobuta-1,3diene was formed in this reaction.

When the ( $\sigma$-butadienyl)palladium complexes 4av, prepared in a stoichiometric reaction of $\mathbf{1 a}$ or $\mathbf{1 b}$ with bromine, were reacted with bromine, the formation of a ( $\sigma$-butadienyl)palladium(IV) tribromi de intermediate (5av in Scheme 9, $X=Y=B r$ ) was observed when following the reaction by low-temperature ${ }^{1} \mathrm{H}$ NMR. At $218 \mathrm{~K}$ compound $\mathbf{4 a v}$ exhibits four different resonance signals at 4.10, 3.76, 3.75, and 3.58 ppm in its ${ }^{1} \mathrm{H}$ NMR spectrum, stemming from the four inequivalent methoxy groups (these are not much different from the shifts observed for 5 av at $218 \mathrm{~K}$, which were found at 4.05, 3.78, 3.73, and 3.58 ppm). This complex (5av) was not as stable in solution as compound 3av, and already at $218 \mathrm{~K}$, the products of reductive elimination were observed. In the course of approximately $1 \mathrm{~h}$, compound 5av was converted completely and cleanly into the 1,4dibromobuta-1,3-diene $\mathbf{2 v}$ and the (Ph-bip)palladium dibromide complex. Similar observations were made for conversion of $\mathbf{4 b v}$ with bromine into $\mathbf{5 b v}$ at $213 \mathrm{~K}$; in this case clean conversion into $\mathbf{2 v}$ took place within $1 / 2 \mathrm{~h}$ at low temperatures (213-218 K).

Reactions of Tetrakis(trifluoromethyl)palladacyclopentadienes 6 with Dihalogens. The reactions of 2,3,4,5-tetrakis(trifluoromethyl)palladacyclopentadienes $\mathbf{6}$ containing a rigid bis(nitrogen) ligand (6a or $\mathbf{6 b}$ ) with an excess of dihalogen did not lead to the formation of the analogous 1,4-dihal obuta1,3-dienes in the cases of reaction with chlorine, bromine, or iodine when short reaction times (1-5 min) were maintained. In all these cases the clean formation of [\{1,2,3,4-tetrakis(trifluoromethyl)-4-hal obuta-1,3dienyl \}palladium(NN) halide] compounds $(\mathbf{7} \mathbf{u}-\mathbf{w}$; Scheme 10) was observed. These compounds were analyzed by ${ }^{1} \mathrm{H},{ }^{13} \mathrm{C}$, and ${ }^{19} \mathrm{~F}$ NMR spectroscopy (see Tables 1 and 2).

\section{Scheme 10}

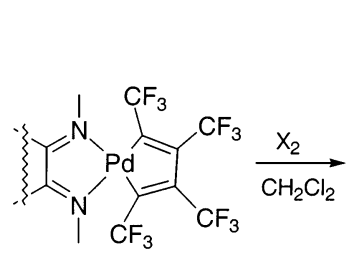

6

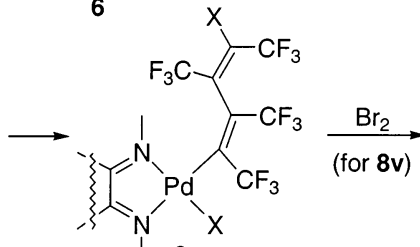

$$
\begin{cases}\mid & \\ N_{N}^{N}=\text { phenyl-bip } & \mathbf{u} ; X=C l \\ \mathbf{I} & \mathbf{w} ; X=\mathrm{Br}\end{cases}
$$

The ${ }^{19} \mathrm{~F}$ NMR spectra of compounds $\mathbf{8 u}-\mathbf{w}$ revealed four quartets, indicating the presence of two separate sets of two cis- $\mathrm{CF}_{3}$ groups on a double bond, ${ }^{43}$ as a result of a perpendicular orientation of the double bonds with respect to each other. This is in agreement with the geometric feature found in the X-ray structure of $\mathbf{4} \mathbf{c w}$, where the torsion angle $C(13)-C(14)-C(17)-C(20)$ amounts to $107.0(6)^{\circ}$ (vide supra).

When compounds $\mathbf{7 u}, \mathbf{v}$ were left standing in solution at room temperature, a new compound was formed over the course of more than 1 day. This conversion could readily be followed by ${ }^{19} \mathrm{~F} N \mathrm{NMR}$, and the appearance of four broad signals at $-51.6,-52.7,-55.9$, and -62.0 ppm for $7 v$ and $-52.8,-53.8,-56.9$, and -63.8 ppm for 7u was observed. Most probably, a cis/trans isomerization of the terminal double of the butadienyl moiety takes place. This is consistent with the observation that when bromine was added to the new product formed from 7v (8v in Scheme 10), a new set of four quartets was observed in the ${ }^{19} \mathrm{~F}$ NMR at $-57.5,-59.1$, and -60.8 ppm (two overlapping quartets), which can be ascribed to the unsymmetric organic butadiene product (Z,E )-1,4-dibromo-1,2,3,4-tetrakis(trifluoromethyl)-1,3butadiene (9).

Reaction of ( $\sigma$-Dienyl)palladium(II) Halide Compounds 4 with Silver Triflate and Isonitriles. Compounds $\mathbf{4 b z}$ and $\mathbf{4} \mathbf{c z}$, having a methyl substituent instead of halogen at the 4-position of the dienyl moiety, which have been previously reported, ${ }^{2 b}$ react with silver triflate in dichloromethane to provide $\mathbf{1 0 b z}$ and $\mathbf{1 0} \mathbf{c z}$ (Scheme 11), respectively, as air-stable compounds after isolation by filtration. Similarly, a bpy compound could also be obtained, but surprisingly, this appeared not to be possible for the putative bip compound.

The unusual low-frequency methoxy signal at 3.28 ppm (see Table 1) is attributed to the carbomethoxy group at the 3-position of the dienyl moiety, the carbonyl function of which is coordinating to palladium. Thereby, the methoxy group of that carbomethoxy moiety is exposed to the anisotropic shielding cone of the $\mathrm{N}$-aryl group of the bian ligand. The ${ }^{13} \mathrm{C}$ NMR data of the carbonyl and methoxy carbons of one carbomethoxy

(43) Kemmitt, R. D.; Kimura, B. Y.; Littlecott, G. W. J . Chem. Soc., Dalton Trans. 1973, 636. 


\section{Scheme 11}

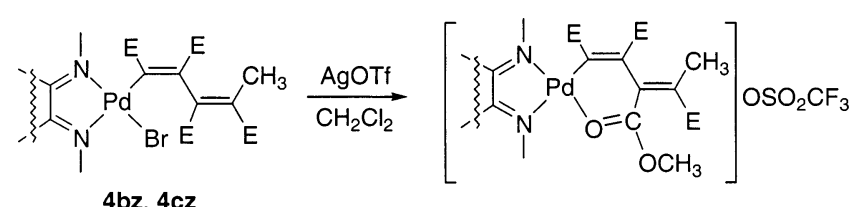
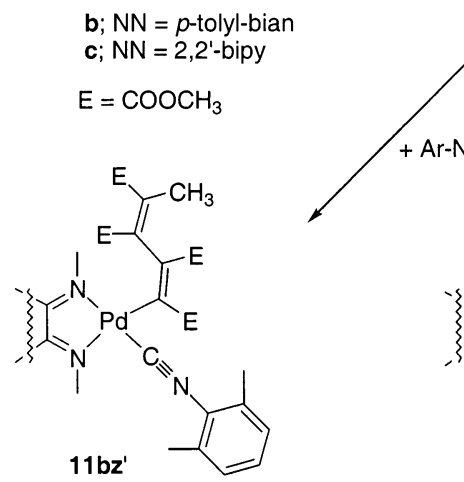

fragment show high-frequency shifts to 179.0 and 56.9 ppm, respectively, which amount to a coordinationinduced shift (CIS) of +5.8 and 2.9 ppm, respectively, as compared to neutral congeners, corroborating such a coordination, although the magnitude of the CIS is rather small when compared to shifts of up to $30 \mathrm{ppm}$ reported for e.g. multiple insertion products of $\mathrm{CO}$ and norbornadiene in $\mathrm{PdCl}\left(\mathrm{CH}_{3}\right)\left(\mathrm{p}\right.$-anisyl-bian). ${ }^{1 c, d}$ These features were not observed in the case of the bpy compound, as expected for a compound that lacks such a shielding $\mathrm{N}$-aryl group. $\mathrm{F}$ or this compound, dimers and ol igomers have most probably been formed, which easily assemble and disassemble, as has been observed before for similar compounds by NMR and X-ray crystallographic evidence. ${ }^{2 b}$ We do not know whether the triflate is associated with the palladium center or either of the ligands or whether the compound exists as an ion pair (no conductivity data are available). Highresolution mass spectra of these compounds indicated the molecular mass minus the triflate ion.

U pon addition of tert-butyl isocyanide or 2,6-dimethylphenyl isocyanide to $\mathbf{1 0 b z}$ and $\mathbf{1 0} \mathbf{c z}$, these ligands occupy the fourth coordination position, thereby readily substituting the coordinating carbonyl of $\mathbf{1 0 b z}$ or disassembling the dimers of $\mathbf{1 0} \mathbf{c z}$, to give $\mathbf{1 1} \mathbf{b z}$ and $\mathbf{1 1} \mathbf{c z}$.

Similar coordination compounds were formed when acetonitrile was added to $\mathbf{1 0 b z}$ and $\mathbf{1 0 c z}$.

X-ray Structure of [1,2,3,4-tetrakis(carbomethoxy)-1,3-pentadienylpalladium(II)(tert-butyl isocyanide) $\left(\sigma^{2} \mathrm{~N}, \mathrm{~N}^{\prime}\right.$-p-tolyl-bian)] Trifluoromethanesulfonate (11 bz). The molecular structure of $\mathbf{1 1} \mathbf{b z}$ with the adopted numbering scheme is shown in Figure 3. Some selected bond lengths and bond angles of $\mathbf{1 1 b z}$ are listed in Table 7. The structure shows that the palladium center is coordinated by the imine nitrogen atoms $N(1)$ and $N(2)$, the isonitrile carbon $C(27)$ and the carbon of the dienyl fragment $\mathrm{C}(28)$. The coordination around the metal center is square-planar, as expected for divalent palladium complexes. The $\mathrm{Pd}-\mathrm{N}$ distances of 2.081(8) and 2.127(8) $\AA$ are comparable or slightly shorter than for other $\mathrm{Pd}$-diimine complexes, e.g. 2.173(5) and 2.145(6) $\AA$ in $\mathrm{Pd}\left(0,0^{\prime}-\mathrm{PP}_{2}\right.$-BIAN)(maleic anhydride), ${ }^{44}$ 2.130(6) $\AA$ in $(\mathrm{BIP}) \mathrm{PdC}(\mathrm{E})=\mathrm{C}(\mathrm{E}) \mathrm{C}(\mathrm{E})=\mathrm{C}(\mathrm{E})$,

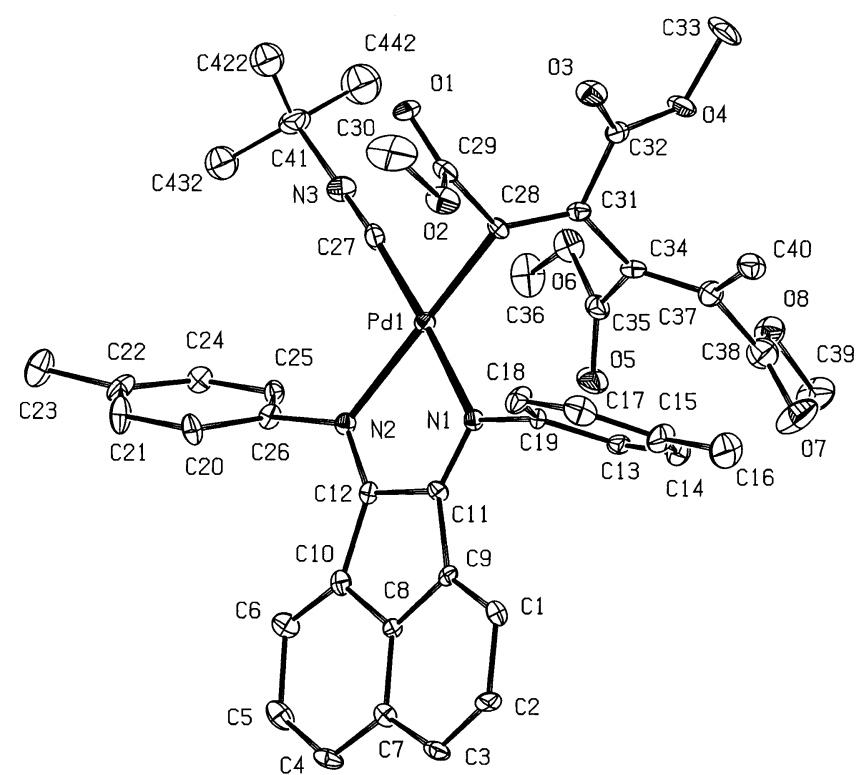

Figure 3. ORTEP presentation ( $50 \%$ probability displacement ellipsoids) of $\mathbf{1 1 b z}$. The triflate anion, hydrogen atoms, and minor tert-butyl disorder have been omitted.

Table 7. Selected Bond Lengths ( $\AA$ ), Bond Angles (deg), and Torsion Angles (deg) of 11bz (E sd's in Parentheses)

\begin{tabular}{llll}
\hline $\mathrm{Pd}-\mathrm{N}(1)$ & $2.081(8)$ & $\mathrm{C}(28)-\mathrm{C}(31)$ & $1.324(14)$ \\
$\mathrm{Pd}-\mathrm{N}(2)$ & $2.127(8)$ & $\mathrm{C}(34)-\mathrm{C}(37)$ & $1.353(16)$ \\
$\mathrm{Pd}-\mathrm{C}(27)$ & $1.928(11)$ & $\mathrm{O}(1)-\mathrm{C}(29)$ & $1.198(13)$ \\
$\mathrm{Pd}-\mathrm{C}(28)$ & $2.013(9)$ & $\mathrm{O}(3)-\mathrm{C}(32)$ & $1.203(13)$ \\
$\mathrm{N}(1)-\mathrm{C}(11)$ & $1.276(12)$ & $\mathrm{O}(5)-\mathrm{C}(35)$ & $1.190(14)$ \\
$\mathrm{N}(2)-\mathrm{C}(12)$ & $1.274(13)$ & $\mathrm{O}(7)-\mathrm{C}(38)$ & $1.231(17)$ \\
$\mathrm{N}(1)-\mathrm{C}(19)$ & $1.429(12)$ & $\mathrm{O}(2)-\mathrm{C}(30)$ & $1.431(15)$ \\
$\mathrm{N}(2)-\mathrm{C}(26)$ & $1.426(12)$ & $\mathrm{O}(4)-\mathrm{C}(33)$ & $1.446(14)$ \\
$\mathrm{C}(11)-\mathrm{C}(12)$ & $1.481(13)$ & $\mathrm{O}(6)-\mathrm{C}(36)$ & $1.451(15)$ \\
$\mathrm{C}(27)-\mathrm{N}(3)$ & $1.144(14)$ & $\mathrm{O}(8)-\mathrm{C}(39)$ & $1.457(15)$ \\
$\mathrm{N}(3)-\mathrm{C}(41)$ & $1.499(14)$ & $\mathrm{C}(37)-\mathrm{C}(40)$ & $1.499(16)$ \\
$\mathrm{N}(1)-\mathrm{Pd}-\mathrm{N}(2)$ & $80.2(3)$ & $\mathrm{Pd}-\mathrm{N}(2)-\mathrm{C}(26)$ & $126.6(6)$ \\
$\mathrm{N}(1)-\mathrm{Pd}-\mathrm{C}(28)$ & $98.0(3)$ & $\mathrm{Pd}-\mathrm{C}(27)-\mathrm{N}(3)$ & $176.2(10)$ \\
$\mathrm{N}(1)-\mathrm{Pd}-\mathrm{C}(27)$ & $176.7(4)$ & $\mathrm{C}(27)-\mathrm{N}(3)-\mathrm{C}(41)$ & $173.9(11)$ \\
$\mathrm{N}(2)-\mathrm{Pd}-\mathrm{C}(28)$ & $176.5(3)$ & $\mathrm{Pd}-\mathrm{C}(28)-\mathrm{C}(31)$ & $129.1(7)$ \\
$\mathrm{N}(2)-\mathrm{Pd}-\mathrm{C}(27)$ & $96.5(4)$ & $\mathrm{C}(28)-\mathrm{C}(31)-\mathrm{C}(34)$ & $123.2(9)$ \\
$\mathrm{Pd}-\mathrm{N}(1)-\mathrm{C}(11)$ & $112.1(6)$ & $\mathrm{C}(31)-\mathrm{C}(34)-\mathrm{C}(37)$ & $122.0(10)$ \\
$\mathrm{Pd}-\mathrm{N}(1)-\mathrm{C}(19)$ & $130.6(6)$ & $\mathrm{C}(34)-\mathrm{C}(37)-\mathrm{C}(40)$ & $125.3(10)$ \\
$\mathrm{Pd}-\mathrm{N}(2)-\mathrm{C}(12)$ & $109.9(6)$ & &
\end{tabular}

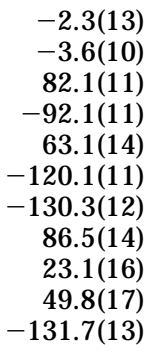

and 2.127(6) and 2.113(7) $\AA$ in (bpy) $\mathrm{PdC}(\mathrm{E})=\mathrm{C}(\mathrm{E}) \mathrm{C}(\mathrm{E})=$ C $(E) .45$

Comparing the known features of the free (p-tolyl)$\mathrm{BIAN}^{46}$ with $\mathbf{1 1 b z}$ shows that the imine bond lengths undergo no significant change upon complexation to

(44) van Asselt, R.; Elsevier, C. J .; Smeets, W. J . J .; Spek, A. L. I norg. Chem. 1994, 33, 1521.

(45) van Belzen, R.; Klein, R. A.; Elsevier, C. J .; Smeets, W. J . J .; Spek, A. L. Recl. Trav. Chim. Pays-Bas, in press.

(46) van Asselt, R.; Elsevier, C. J .; Smeets, W. J . J .; Spek, A. L.; Benedix, R. Red. Trav. Chim. Pays-Bas 1994. 113, 88. 
palladium. However, upon coordination the deviation of the diimine moiety of the (p-tolyl)-BIAN decreases as appears from the comparison of the torsion angles of $11 \mathbf{b z} \mathrm{N}(1)-\mathrm{C}(11)-\mathrm{C}(12)-\mathrm{N}(2)$ of $-2.3(13)^{\circ}$ and $\mathrm{C}(9)-$ $\mathrm{C}(11)-\mathrm{C}(12)-\mathrm{C}(10)$ of $-3.6(10)^{\circ}$ with similar angles of $-6.5(3)$ and $-5.6(2)^{\circ}$ in the uncoordinated (p-tolyl)BIAN. Furthermore, the position of the p-tolyl groups with respect to the plane of the naphthalene is altered; in the complex the ring oriented toward the dienyl fragment (attached to $N(1)$ ) is al most perpendicular to the naphthalene $(C(18)-C(19)-N(1)-C(11)$ is -92.1$\left.(11)^{\circ}\right)$ due to the steric interactions with the dienyl group, whereas the ring on the less hindered position (attached to $\mathrm{N}(2)$ ) is closer to the value of the free ligand of $-125.9(3)^{\circ}\left(\mathrm{C}(25)-\mathrm{C}(26)-\mathrm{N}(2)-\mathrm{C}(12)\right.$ is $\left.-120.1(11)^{\circ}\right)$.

The dienyl group is positioned perpendicular to the plane of coordination. The configuration around the double bonds is E,Z; i.e., the ester groups are in a cis,cis position, as could be expected on the basis of our earlier reported work. ${ }^{2 b}$ However, it was not selfevident, since it was reported that $E, Z$ dienyl fragments, initially formed by a double cis insertion of alkynes in cyclopalladated compounds (several X-ray structures of such complexes were published ${ }^{47}$ ) or a dimerization of acetylenes, ${ }^{48}$ underwent a cis/trans i somerization to the $\mathrm{E}, \mathrm{E}$ isomers. It was recently also suggested that the isomerization is intrinsic to the second alkyne insertion, ${ }^{49}$ and if that would be the case, no $\mathrm{E}, \mathrm{E}$ dienyl fragment can be formed in $\mathbf{5 b}$ or any of its precursors.

The double bonds of the dienyl unit make an angle of $-130.3(12)^{\circ}$ relative to each other, indicating that no conjugation can occur, and this is indeed reflected in the bond lengths $C(28)-C(31)$ and $C(34)-C(37)$ of 1.324(14) and 1.353(16) $\AA$, which are comparable with the values in other palladium dienyl complexes, e.g. $1.344(14)$ and $1.331 \AA$ in (bpy) PdC $(\mathrm{tBu})=\mathrm{C}\left(\mathrm{CH}_{3}\right) \mathrm{C}$ $\left(\mathrm{CH}_{3}\right)=\mathrm{C}(\mathrm{tBu})^{50}$ and the noncoordinating alkene of $1.326(3)$ or $1.335(21) \AA$ in double alkyne insertion products of a cyclopalladated complex ${ }^{51,52}$ and 1.332(7)

$\AA$ in $(b p y) P d C(E)=C(E) C(E)=C(E) .^{2 b}$ Also, the value for the $\mathrm{Pd}-\mathrm{C}\left(\mathrm{sp}^{2}\right)$ distance of $2.013(9) \AA$ is similar to the ones found for the complexes mentioned above, viz. 2.027(10), 2.007(2), and 1.981(5) $\AA$, respectively. The $\mathrm{Pd}-\mathrm{C}(\mathrm{sp})$ distance of $1.928(11) \AA$ falls within the range of reported bond lengths for a variety of palladium complexes containing isonitriles, e.g. 1.909(16) $\AA$ in [ $(u$ anilino) $\mathrm{Pd}\left(\mathrm{C}_{6} \mathrm{~F}_{5}\right)$ (tert-butylNC) $]_{2}, 531.925(5) \AA$ in $\mathrm{PdCl}_{2^{-}}$ (tert-butylNC)(diphenyl(2-pyridyl)phosphine), ${ }^{54}$ 1.885(7)

(47) (a) Bahsoun, A.; Dehand, J .; Pfeffer, M.; Zinsius, M.; Bauaoud, S. E.; Le Borge, G. J . Chem. Soc., Dalton Trans. 1979, 547. (b) Tao, W.; Silverberg, L. J .; Reingold, A. L.; Heck, R. L. Organometallics 1989, 8, 2550. (c) Albert, j .; Granell, J .; Sales, J . J . Organomet. Chem. 1989 379, 177. (d) Pfeffer, M.; Rotteveel, M. A.; Sutter, J . P.; de Cian, A.; Fischer, J.J Organomet. Chem. 1989, 371, C21.

(48) Taylor, S. H.; Maitlis, P. M. J . Am. Chem. Soc. 1978, 100, 4700. (49) Ryabov, A. D.; van Eldik, R.; Le Borgne, G.; Pfeffer, M. Organometallics 1993, 12, 1386.

(50) Kelly, E. A.; Bailey, P. M.; Maitlis, P. M. J . Chem. Soc., Chem. Commun. 1977, 289.

(51) Ryabov, A. D.; van Eldik, R.; Le Borgne, G.; Pfeffer, M. Organometallics 1993, 12, 1386

(52) Albert, J .; Granell, J .; Sales, J . J . Organomet. Chem. 1989, 379, 177. Klein, R. A.; Elsevier, C. J .; Kooijman, H.; Veldman, N.; Spek, A. L. To be submitted for publication.

(53) Ruiz, J .; Martinez, M. T.; Vicente, C.; Garcia, G.; Lopez, G.; Chaloner, P. A.; Hitchcock, P. B. Organometallics 1993, 12, 4321.

(54) De Munno, G.; Bruno, G.; Arena, C. G.; Drommi, D.; Faraone,

F. J . Organomet. Chem. 1993, 450, 263. and 1.935(7) $\AA$ in [( $u$-1,8-diisocyano-p-menthane) $\mathrm{Pd}(\mathrm{Br}$ )$\mathrm{Cl}_{2},{ }_{2}$, and 2.027(6) $\AA$ in 1,1-(tert-butylNC) $)_{2}-2-\left(\mathrm{NCH}_{3}\right)_{3-}$ 2-carba-1-pallada-cl oso-decaborane. ${ }^{56}$ The other features of the isonitrile show no anomalies; thus, a normal triple bond is observed and the isonitrile is almost linear.

\section{Discussion}

For the addition of molecular halogens to metallacyclic compounds, several mechanisms may be envisaged. One may invoke oxidative addition of the halogen, to give a diorgano-dihalo-palladium(IV) species, and consecutive stereospecific reductive elimination of the carbon-halogen bond to give $\mathbf{4}$ via $\mathbf{3}$ (Scheme 6). This sequence of events is in agreement with the relative rates for reaction with the various dihalogens and with the observed symmetry of intermediates as indicated by the NMR spectra (see above). Hence, we postulate the mol ecular structures of the intermediates dibromo$\{2,3,4,5$-tetrakis (carbomethoxy)butadiene-1,4-diyl $\}$ (phenyl-bip)palladium(IV) compound 3av, and the analogous (bian)palladium(IV) compound 3bv, which are the palladium(IV) compounds arising from oxidative addition of molecular bromine to $\mathbf{l a}$ to bromine. Most probably, for the other halogens similar intermediates are formed.

In view of the order of the rate of reaction, which decreases in the order $\mathrm{Cl}>\mathrm{Br} \gg \mathrm{I}$, radical reactions or a cycloaddition reaction of the molecular hal ogen to the pall adacycle are less probable. Furthermore, occurrence of cycloaddition would involve dissymmetric intermediates, whereas in the present case, clearly, the intermediate is of high symmetry as seen from NMR (see above).

The observed order in reactivity of the palladacyclopentadienes with dihalogens $(\mathrm{Cl}>\mathrm{Br} \gg \mathrm{I})$ is consistent with a rate-determining heterolytic splitting of the halogen-halogen bond, as is observed in oxidative additions; it points to polar addition of the molecular halogens in an $\mathrm{S}_{\mathrm{N}} 2$ type process. This type of bond breaking is also observed in, for instance, the addition reaction of dihal ogens to al kenes and in other oxidative addition reactions of palladium complexes with organic halides. ${ }^{57}$ The interaction of the metal center with the dihalogen polarizes the halogen-halogen bond, eventually producing an ion pair $\mathrm{PdX^{+ }} \mathrm{X}^{-}$, which rapidly forms the oxidative addition product $\mathbf{3}$, in analogy with the reaction of primary alkyl halides or dihalogens with platinum complexes. ${ }^{58}$ The resulting tetravalent palladium complex (3) is not stable in solution at room temperature and reductively eliminates one of the apical halogens with one of the equatorial carbon atoms of the palladacyclopentadiene to give a ( $\sigma$-butadienyl)palladium(II) complex (4). Compound $\mathbf{3}$ is stable in solution for some time at low temperatures. Similar complexes containing phosphorus ligands instead of nitrogen ligands

(55) Perreault, D.; Drouin, M.; Michel, A.; Harvey, P. D. Inorg Chem. 1992, 31, 2740 .

(56) Carrol, W. E.; Green, M.; Stone, F. G. A.; Welch, A. J . J . Chem Soc., Dalton Trans. 1975, 2263.

(57) Canty, A. J . Acc. Chem. Res. 1992, 25, 83.

(58) (a) Ferguson, G.; M onaghan, P. K.; Parvez, M.; Puddephatt, R. J. Organometallics 1985, 4, 1669. (b) Puddephatt, R. J .; Scott, J . D. Organometallics 1985, 4, 1221. (c) van Beek, J . A. M.; van Koten, G.; Smeets, W. J .J .; Spek, A. L. J . Am. Chem. Soc. 1986, 108, 5010. (d) Wehman, E.; van Koten, G.; Knaap, C. T.; Ossor, H.; Pfeffer, M.; Spek, A. L. Inorg. Chem. 1988, 27, 4409. 
have never been observed. 59 The relative stability of $\mathbf{3}$ may be due to the strong donor capacity of the bi dentate nitrogen ligands and their low trans influence. In fact, 3 constitutes one of the very few (diorgano)(dihalo)palladium(IV) species ever observed. ${ }^{5,6}$

The results of the calculations are consistent with the above conclusions. $\mathrm{Br}_{2}$ interacts preferentially with the pal ladium atom prior to the oxidative addition. Whether or not this interaction leads to a genuine intermediate or to a transient species under the reaction conditions is difficult to assess. The entropy change accompanying the adduct formation is negative and thus opposes the energy change. Its precise magnitude and the magnitude of the terms contributing to the enthalpy cannot be obtai ned easily from computations, since anharmonic corrections have to be included for systems involving noncovalent interactions. ${ }^{60}$ The enthal py change should favor the formation of an adduct, but the corresponding free energy change is probably close to zero or even positive, at least for $\mathrm{Br}_{2}$. Adducts of this type have been observed experimentally between di iodine and a Pt(II) complex. ${ }^{59 \mathrm{c}}$ The computed $\mathrm{Br}-\mathrm{Br}$ elongation in the palladium system $(0.07 \AA)$ is somewhat smaller than that one observed in the $I_{2}$ adduct $(0.10 \AA)$. This relatively small elongation is most likely the result of a four-orbital interaction, two of which are doubly occupied (the $4 \mathrm{~d}_{z^{2}}$ of $\mathrm{Pd}$ and the $\sigma$ of $\mathrm{Br}_{2}$ ) and two others are empty (the $5 \mathrm{~s}$ of $\mathrm{Pd}$ and the $\sigma^{*}$ of $\mathrm{Br}_{2}$ ). N ote that a somewhat similar pattern has been found in the chargetransfer complex between $\mathrm{Br}_{2}$ and $\mathrm{C}_{2} \mathrm{H}_{2}$; there the $\pi$ orbital of $\mathrm{C}_{2} \mathrm{H}_{2}$ would play the role of the $\mathrm{d}_{z^{2}}$ orbital in the Pd system. ${ }^{61}$ There would be no equivalent of the empty Pd 5s orbital, however. That the platinum(II)$\mathrm{I}_{2}$ adduct involves a greater amount of charge transfer from the dihalogen to the metal is consistent with the lower energy of the $6 \mathrm{~s}$ orbital of Pt compared to $5 \mathrm{~s}$ of $\mathrm{Pd}$ and with the greater polarizability of diiodine compared to dibromine.

We have not determined the transition state for the subsequent oxidative addition of $\mathrm{Br}_{2}$, since it most likely involves, by analogy to the addition of $\mathrm{Br}_{2}$ to alkenes, a bromonium ion that is stabilized by $\mathrm{a} \mathrm{Br}_{3}{ }^{-}$counteranion and by solvent effects, the treatment of which is outside the scope of the present calculations. This oxidative addition is exothermic, the $\mathrm{Pd}(\mathrm{IV})$ complex $\mathbf{C}$ being 4.3 kcal mol-1 more stable ( $\Delta \mathrm{G}$ value) than the separated $\left[(\mathrm{HNCH}=\mathrm{CHNH}) \mathrm{Pd}\left(\mathrm{C}_{4}(\mathrm{CN})_{4}\right)\right]+\mathrm{Br}_{2}$ reactants (the corresponding $\Delta \mathrm{E}$ and $\Delta \mathrm{H}$ values are 16.7 and $15.4 \mathrm{kcal}$ $\mathrm{mol}^{-1}$, respectively; see Table 6). The finding that E 2 is more stable than $\mathbf{C}$ by $2.4 \mathrm{kcal} \mathrm{mol}^{-1}$ ( $\Delta \mathrm{G}$ value) is also consistent with the obtention of $\mathbf{4}$ as the final product. In fact the rearrangement of $\mathbf{E} \mathbf{1}$ to $\mathbf{E} \mathbf{2}$ provides the driving force for the overall reaction.

The organometallic products $\mathbf{4}$ of the stoichiometric reactions of $\mathbf{1}$ with dihalogens all have a butadienyl fragment with an $E, E$ configuration, as is shown in the crystal structure of $\mathbf{4 c w}$; i.e., both double bonds have a cis configuration. The computed structures of $\mathbf{E} \mathbf{1}$ and

(59) (a) Moravskiy, A.; Stille, J . K. J . Am. Chem. Soc. 1981, 103, 4182. (b) Stille, J. K. In TheChemistry of Metal-Carbon Bond; Hartley, F. R., Patai, S., Eds.; Wiley: New York, 1985; Vol. 2, p 625.

(60) (a) Müller-Dethlefs, K.; Hobza, P. Chem. Rev, 2000, 100, 143.

(b) Kim, K. S.; Tarakeshwar, P.; Lee, J. Y. Chem. Rev. 2000, 100, 4145.

(61) Bianchini, R.; Chiappe, C.; Lo Moro, G.; Lenoir, D.; Lemmen,

P.; Goldberg, N. Chem. Eur. J . 1999, 5, 1570.

\section{Scheme 12}

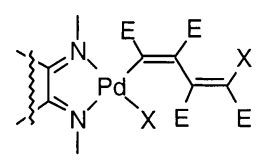
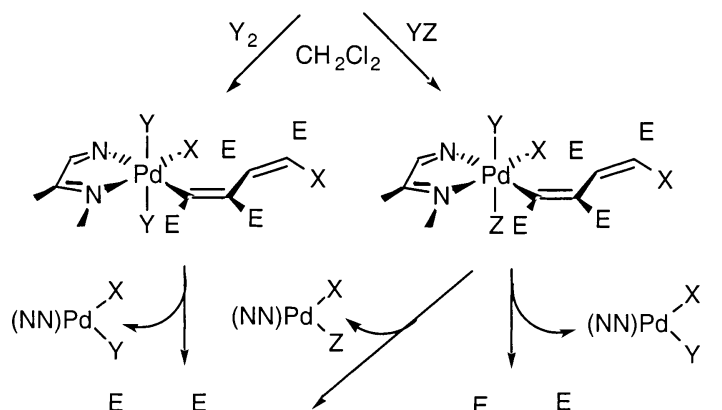<smiles>[Y]C(F)=C([X])C(F)=C([X])F</smiles><smiles>[X]C(F)=C(F)C(F)=C([Z])F</smiles>

$\mathrm{X}=\mathrm{Cl} ; \quad \mathrm{Y}=\mathrm{Br}$

$\mathrm{X}=\mathrm{Br} ; \mathrm{Y}=\mathrm{Cl}$

$X=1 ; Y=B r$

$\mathrm{X}=\mathrm{Br} ; \mathrm{Y}=\mathrm{Cl} ; \mathrm{Z}=\mathrm{I}$

E2 also display an E,E configuration of the $\sigma$-butadienyl fragment (vide supra). This was not self-evident, since several reports have been made of isomerization in dienyl palladium complexes. Although it was recently assumed that in double acetylene insertions the isomerization is intrinsic to the second insertion reaction, 62 also a stepwise isomerization of a dienyl fragment has been observed. ${ }^{63}$ Such a stepwise isomerization was also observed for the ( $\sigma$-butadienyl)palladium complexes containing trifluoromethyl substituents (7 to 8). It is not exactly clear in what respect the substituents determine the occurrence of any isomerization. It has been suggested that the steric requirements of the $\mathrm{X}$ and the $\mathrm{E}$ substituents might be responsible.

The facile isolation of complexes $\mathbf{4}$ allowed for the study of selectivity in the reductive elimination reactions in ( $\sigma$-butadienyl) $\mathrm{Pd}^{\prime \mathrm{V}}$ trihalide complexes containing different halides. Up until now, only studies have been carried out on the selectivity of the reductive elimination in tri(organo)Pd $\mathrm{I}^{\mathrm{IV}}$ compounds containing different alkyl and aryl groups. ${ }^{6,8}$ The product of a reductive elimination from the palladium trihalide complexes presented in this work was al ways the (E,E)diene, which is unsymmetrically substituted at the 1and 4-positions with distinguishable halides $\mathrm{X}-\mathrm{Z}$ (Scheme 12).

Unsymmetric 1,4-di halo-1,3-butadienes with two different halogens are formed by adding an excess of a second, other dihalogen to a solution of the bromine adduct (4av) in dichloromethane at room temperature (see above). From the product distribution it was inferred that the reductive elimination takes place exclusively between the dienyl fragment and the incoming hal ogen (Scheme 10). When chl oro-iodide was used, a $90 \%$ preference was observed for the elimination of the chloride. This same high preference was observed when the palladacycle 1 was reacted with an excess of chloro-iodide, after which 1,4-dichloro-, 1-chloro-4-iodo-

(62) Ryabov, A. D.; van Eldik, R.; Le Borgne, G.; Pfeffer, M. Organometallics 1993, 12, 1386.

(63) Taylor, S. H.; Maitlis, P. M. J . Am. Chem. Soc. 1978, 100, 4700. 
and 2,4-diiodobuta-1,3-diene were obtained in a ratio of $72: 26: 2$, respectively. More important than learning the difference in the selectivity from the reaction of $\mathbf{4 a v}$ with chloro-iodide is the observation that no bromide is incorporated in the diene, which indicates that the reductive elimination uniquely takes place by incorporating the halide from the axial position in the octahedral Pd(IV) compound ( $\mathrm{Y}$ or Z in Scheme 10). Thus, no isomerization takes place after the oxidative addition of the halogen, as opposed to most eliminations from tris(organo)Pd $d^{\prime V}$ complexes. In the latter case usually an exchange or scrambling of organic groups occurs, during which the halide remains in the axial position, resulting in the formation of a mixture of coupling products. The absence of isomerization has been observed in the case of another complex that contains a rigid bis(nitrogen) ligand, viz. the tetravalent palladium dihalide complex ( $p$-tolyl)BIAN PdIVMezl ${ }_{2}{ }^{6}$

\section{Conclusion}

It has been shown that by using a rigid bidentate nitrogen ligand one may stabilize (dihalo)(di organo)PdIV intermediates, which are intermediates in the synthesis of $(E, E)$-dihalo-1,3-dienes from a palladacycl opentadiene and molecular halogen. Most likely, a process of trans oxidative addition of the molecular halogen to the $\mathrm{Pd}(\mathrm{II})$ center to give a transient (dihalo)(diorgano)$\mathrm{Pd}(\mathrm{IV})$ species occurs, which is followed by reductive elimination of a $\mathrm{C}\left(\mathrm{sp}^{2}\right)$-halogen fragment. It was also shown that the process of reductive elimination of the $\mathrm{C}\left(\mathrm{sp}^{2}\right)$-halogen moiety is fast as compared to the dissociation of a halogen and subsequent isomerizations. Thus, the reductive elimination proceeds stereospecifically, involving interactions between an apical halogen and an equatorial carbon atom. This enables the selective preparation of 1,4-dihalo-1,3-butadienes with different halides on the 1- and 4-positions. The difference in the reactivity of the respective $\mathrm{C}-\mathrm{X}$ bonds in the resulting unsymmetrical dienes is expected to be very useful for their further chemical elaboration: e.g., they may be applied as electrophiles in carbon-carbon bond forming reactions such as the Heck reaction or crosscoupling and carbostannylation reactions.

Acknowledgment. This work was supported in part (A.L.S. and N.V.) by the Council for Chemical Sciences of The Netherlands Organization for Scientific Research (CW-NWO). A.D. thanks the CNRS for financial support. The calculations were carried out on the workstations of our laboratory and of the Centre Universitaire Régional de Ressources I nformatiques (CURRI) of Strasbourg. We thank Dr. L. Padel and Mrs. S. Fersing for their help and technical assistance.

Supporting Information Available: Tables of crystal data and details of the structure determinations, final coordinates and equivalent isotropic displacement parameters, hydrogen atom positions, anisotropic displacement parameters, and bond distances and bond angles for $\mathbf{4} \mathbf{c w}$ and $\mathbf{1 1 b z}$. This material is available free of charge via the Internet at http://pubs.acs.org.

OM020586T 